\title{
Smart Organizations as a Source of Competitiveness and Sustainable Development in the Age of Industry 4.0: Integration of Micro and Macro Perspective
}

\author{
Anna Adamik ${ }^{1}$ (D) and Dorota Sikora-Fernandez ${ }^{2, *(D)}$ \\ 1 Faculty of Management and Production Engineering, Lodz University of Technology, 266 Piotrkowska Str., \\ 90-924 Lodz, Poland; anna.adamik@p.lodz.pl \\ 2 Faculty of Management, University of Lodz, 22/26 Matejki Str., 90-237 Lodz, Poland \\ * Correspondence: dorota.sikora@uni.lodz.pl; Tel.: +48-426-356-290
}

Citation: Adamik, A.

Sikora-Fernandez, D. Smart

Organizations as a Source of

Competitiveness and Sustainable Development in the Age of Industry 4.0: Integration of Micro and Macro Perspective. Energies 2021, 14, 1572. https://doi.org/10.3390/en14061572

Academic Editor: Patrycja Hąbek

Received: 12 February 2021

Accepted: 10 March 2021

Published: 12 March 2021

Publisher's Note: MDPI stays neutral with regard to jurisdictional claims in published maps and institutional affiliations.

Copyright: (c) 2021 by the authors. Licensee MDPI, Basel, Switzerland. This article is an open access article distributed under the terms and conditions of the Creative Commons Attribution (CC BY) license (https:// creativecommons.org/licenses/by/ $4.0 /)$.

\begin{abstract}
The Industry 4.0 Revolution that is taking place nowadays means that organizations face not only new opportunities, but also challenges related to the identification of their role in creating a modern smart world. The economies of many countries are under the significant and growing influence of various types of organizations, not only strong international business corporations, but also, more and more often, smaller but intelligent ones called smart organizations IR 4.0. Due to their unique characteristics, intelligent organizations are better able than others to cope with technological breakthroughs, social, and cultural problems as well as to compete effectively and develop in an environmentally sustainable way. With their growing potential, they are strengthening the economies of their countries of origin and daily operation. Their growing role is also visible in the processes of shaping competitiveness and achieving the sustainable development objectives of the European Union (EU). The countries that are able to organize an environment on their territory that is conducive to the smart organization's development are clear examples not only of a high market competitiveness, but also of a dynamically growing commitment to the effective implementation of the challenges associated with the 17 objectives of sustainable development of the contemporary EU, according to the 2030 Agenda for Sustainable Development. This allows for a conclusion that the identification of the key factors for a smart organization's development makes it possible to monitor and provide targeted support for the development not only of these organizations, but also for the competitiveness and sustainability of individual countries, both from the EU and other regions of the world. In light of the above, the aim of this article is therefore to propose an effective tool to monitor the use of power of smart organizations in the processes of building the competitiveness and sustainable development of countries, with particular reference to the EU. To achieve this objective, we constructed a synthetic power of smart organizations index (PSOI) based on previously collected data from EUROSTAT. This tool allows for the integration of micro (organization level) and macro (country level) economic aspects into a single construct. Based on the analysis of its results, countries wishing to actively engage in the development of their own and the EU's smartness and sustainability can be offered several more or less intense navigation paths to market success, based on the development of smart organizations.
\end{abstract}

Keywords: Industry 4.0; smart technologies; sustainability; smart and sustainable organizations; smart and sustainable EU

\section{Introduction}

We are witnessing the fourth industrial revolution, the so-called Industry 4.0 Revolution, so we live in the smart world of IR 4.0 transition [1-4]. This world brings not only new opportunities and challenges, but also new requirements in terms of the concepts and principles of effective operation and competition on the IR 4.0 scale. This applies to both the social and economic spheres $[5,6]$ as well as their interconnection, impact [7], and 
even dependence [8]. This is due, among other things, to the deepening and dynamically propagating role of modern technologies, especially information science and information technologies, albeit not only [9]. Based on their effective use, new smart competencies, smart employees, smart managers, smart products [10], smart projects, smart technologies, smart factories [11], smart organizations, and smart industries [12,13] are born, and furthermore, smart cities [14-18], regions [19,20], and countries or economies. As a result, we create for everyone a smart Europe, smart world, and generally a smart future [21].

In 2012, the World Economic Forum published "The Europe 2020 Competitiveness Report: Building a More Competitive Europe". This Report researched and monitored the extent to which the EU was making progress to achieve the competitiveness goals set in its "Europe 2020" strategy to achieve smart, sustainable, and inclusive growth. Its reading inspired the authors to start looking for potential sources (i.e., concrete catalysts of success) with a specific smart character. Questions also arose as to whether only new technologies significantly influenced this character, or whether there were any other conditions (e.g., social) with equally important impact, and how to what extent smart organizations contribute to achieving the EU's sustainable development goals. It was not easy to find answers to these questions.

The analysis was greatly supported by the results of the report "The EU Regional Competitiveness Index 2019 [22] and the World Economic Forum (WEF).

As a preliminary remark, it has been assumed that after the World Economic Forum (WEF), the phenomenon responsible for the smartness of Europe involves competitiveness and sustainability at the national level, which is generally seen as "a set of institutions, policies, and factors that determine the level of productivity of a country". However, such a broad and, on the other, aggregated approach was not satisfactory. Further research has drawn the authors' attention to the special role of "regions" in the analyzed phenomenon. According to Meyer-Stamer [23], "we can define (systemic) competitiveness of a territory as the ability of a locality or region to generate high and rising incomes and improve the livelihoods of the people living there" [24]. However, this approach still did not provide a clear answer to the question raised, as this definition is based entirely on the benefits to people living in a region and does not assess the strengths or weaknesses of companies. A step in the right direction came in the form of the approach proposed by Lewis Dijkstra used in 2019 in "the EU regional competitiveness index 2019". The author noted that "Regional competitiveness is the ability of a region to offer an attractive and sustainable environment for firms and residents to live and work" [25]. This approach drew the attention of the authors of the study to the special role of companies, or more broadly, organizations. On the one hand, they select, collect, process, develop, and exploit the smart resources and skills available in their surroundings (city, region, country); on the other, it is their smart (smartness) activity that determines and delineates the dynamics of wider socio-economic, sustainable development, or the competitiveness of individual cities, regions, economies, and even larger economic systems including the EU. Further analysis also strongly confirmed the important links between organizational smartness, the achievement of sustainability goals, and competitiveness.

Therefore, it seemed crucial to identify the essence and specificity of the activity, and the real role in a contemporary smart EU/world of the so-called smart organizations. A literature review of the issue showed a significant research gap. Both the Web of Science and Scopus databases show a clear lack of research in this area. While numerous results of research on the competitiveness of countries, regions, industries, or selected types of organizations are available, there are no such analyses for their specific "smart" varieties. Much has been written about the specificity and role of different types of organizations in today's economy, but there is still little research on deepening the knowledge on smart organizations. Even queries in research databases for terms that are close to "smart firm", "smart business", or "intelligent organization" did not improve the situation (see Table 1). 
Table 1. Systematic review of the literature on "smart organization" and related terms in the Web of Science and Scopus databases (2020).

\begin{tabular}{ccccc}
\hline Search Research by Title & WoS/Generally & $\begin{array}{c}\text { WoS/Busines, Management } \\
\text { and Economics }\end{array}$ & Scopus/Generally & $\begin{array}{c}\text { Scopus/Business, } \\
\text { Management, and } \\
\text { Accounting }\end{array}$ \\
\hline & & Analyze search results (number of papers) & \\
\hline "Smart business" & 52 & 26 & 97 & 47 \\
"Intelligent organization" & 29 & 12 & 52 & 18 \\
"Smart organization" & 11 & 10 & 37 & 26 \\
"Smart firms" & 1 & 1 & 4 & 4 \\
\hline
\end{tabular}

Source: Own studies based on the WoS and Scopus databases.

Therefore, considering the era in which we live, there seems to be a significant research gap. Other reasons for undertaking this research topic include:

1. A lack of effective, systematic, integrated approach, and cooperation between various groups of stakeholders including businesses, consumers, politicians, the world of science, and non-governmental organizations to build competitiveness and achieve the 2030 Agenda for Sustainable Development Goals.

2. A lack of easy-to-use and clear tools for monitoring the maturity of smart organizations that influence the level of competitiveness and the achievement of sustainable development goals in countries of their operation.

3. A lack of established ways to support the navigation of countries wishing to accelerate the processes of building competitiveness and achieving sustainable development goals.

The aim of the study was to reduce these gaps.

Many years of research on the issue have allowed the authors to put forward a thesis that the sources of success, sustainability, or simply competitiveness of each of the "smart entities" (cities, regions, countries) depend on the "power" and maturity of the smart organizations/companies cooperating with them. In order to join the discussion on the so-called factors supporting the construction of smart and sustainable Europe, it was assumed that the main goal of the paper was to identify and map the key variables of smart organization IR 4.0 as well as to propose and verify a tool for monitoring the manner of building the sustainability and competitiveness of smart Europe IR 4.0 based on the Power of Smart Organizations Index (PSOI).

With the above in mind, subsequent parts of the study attempted to bring closer the specificity of organizations in the Age of Industry 4.0. It started with a description of the requirements of the IR 4.0 Age and the concept of "smart", then an attempt was made to identify the essence of smart and sustainable organizations as well as the sources and consequences of smart organizations' "power". The next step involved describing the concept and methodology of the empirical studies undertaken to achieve the objectives of the study and to discuss the collected results. In Section 5, there are references to studies by other researchers on the issue as well as an indication of the proposed directions of further research. In Section 6, research conclusions are proposed. Theoretical considerations were based on a review of the world literature on management sciences, organizational sciences, and strategic management, with particular emphasis on the requirements of the Industry 4.0 Age. Empirical analyses were carried out on the basis of Eurostat data for 2018 and 2019 for the 28 EU Member States, based on the proprietary synthetic Power of Smart Organization Index (PSOI).

\section{Organizations in the Age of Industry 4.0}

\subsection{The Specifics of the Age of Industry 4.0 and the Concept of "SMART"}

The starting point for the analyses was understanding the specificity of the Industry 4.0 (IR 4.0) Age. It is related to increasing globalization, the ever-accelerating pace of techno- 
logical, social, and cultural progress, and the consequent fourth industrial revolution-the so-called Information Technology (IT) revolution. Together, they form a specific environment for modern organizations, in which two functional realities: real (PR-physical reality) and virtual (cyberspace, VR-virtual reality), merge. This leads to the development of various networks of cooperation between organizations (network cooperation, virtual network), computer-based advanced technologies, digital solutions, robotics (CPS - Cyber-Physical Systems), real-time big data processing (BDA—Big Data Analytics), Internet connections (IoT-Internet of Things, IoS-Internet of Services), close, partnershiporiented relations between people (Cooperation, Partnering, Team Working), and organizations (SP-Strategic Partnering, KP-Knowledge Partnering, Coopetition) as well as relations between machines themselves (M2M-Machine to Machine Communications, Artificial Intelligence, Neural Networks) [26-28]. It is therefore an extended conceptual unit, meaning a knowledge-based and innovative solution-based integration/cooperation of intelligent people, machines, and systems, resulting in changes in production and service processes in order to increase their quality, speed, power, and flexibility (e.g., in terms of available capacities, and assortment in order to customize them more strongly) $[2,29,30]$. In this way, it poses specific competence, technological, and organizational challenges to modern market players [31-37].

In order to meet them, contemporary organizations or other stakeholders should be part of the essence of the smart concept/state [28]. Smart means that innovations are implemented in an intelligent, proactive, purposeful, aspirational, and goal-oriented manner, which leads to the achievement of a desired future [38]. The smart state is dependent on factors such as the environment, culture, and the value system of a given person or organization. Nevertheless, the overall concept of a smart future should be based on the search for a living environment that is superior to what is present now [39]. The smart state should support the development of intelligent solutions to complex strategic problems, in order to ensure human functioning [40] and, as such, requires much more from modern organizations and their environment than just owning and operating smart gadgets, ICTs, convergence strategies, and government support. It has to be based on a solid foundation of future-oriented soft innovations such as social justice, rule of law, transparency, accountability, cohesive collective wisdom of people, sustainable development, social cohesion, and shared visions and goals [41,42]. Against such a background, people's knowledge and information become a new currency by leveraging networks and devices they share to navigate any exchanges and negotiations, be they individual or social, personal, or professional, driven by human interactions or machine interfaces, in order to generate added value by producing huge amounts of data in need of processing and analysis [43].

In conclusion, the attribute of a "smart state" comes from the manner in which an organization develops and uses knowledge as an integrated resource that combines the expertise provided by human resources with the support offered by technology-based platform [44]. The concept of a smart organization is thus based on the usage and justification that lead to harnessing information-age tools and management practices within an organization in a specific way. This makes the smart world an alluring prospect that involves intelligence that permeates into things that surround us including physical and virtual objects, social interactions, and human thinking. One ultimate goal of such a smart world is an integrated hyperspace made of virtual, physical, social, and thinking dimensions. This would involve complex interconnections and intelligent relations between the perception of the physical world, interactions in the virtual sphere, social correlation, and cognitive thinking interwoven into every possible aspect of our daily lives $[21,45,46]$.

\subsection{Smart and Sustainable Organizations}

Modern economies are under the significant and growing influence of various types of organizations, not only strong, international business corporations, but also increasingly smaller but intelligent organizations that are now known as smart organizations 
IR 4.0. [44,47-51]. Research and development (R\&D) contributed substantially to the emergence of smart organizations [52].

Generally speaking, organizations are open social and technical systems with their own specific objectives and an adequately adapted organizational structure. However, smart organizations have specific requirements for each of these elements (social, technical, goal, and structure resources used) because of their focus on the needs of the Age of Industry 4.0.

The term "intelligent organization" evolved in the 1990s due to the development of ICT, dynamically changing economic surroundings and the growth in market competition [53]. Within the European Commission's research program, "Information Society Technologies", the term "smart organization" was coined for organizations that are "knowledge-driven, inter-networked, and dynamically adaptive to new organizational forms and practices, learning as well as agile in their ability to create and exploit the opportunities offered" [54]. An intelligent/smart organization is marked by a transitory layout and agile structure [44] learning organization, with the capacity for creating, gaining, organizing, and sharing knowledge and using it for the purpose of increasing the operational effectiveness, sustainable development, and competitiveness in the global market. A smart organization is one that bases its philosophy of operation on sustainability and knowledge management. Knowledge resources include data concerning one's customers, products, processes, environment, etc. both in a codified (documents, databases) and non-codified (the employees' knowledge) form. Such co-dependency of these elements, when put in practice, would have to employ advanced ICT solutions embedded into the framework of an economic organization's ICT system. An intelligent organization uses not only technical and technological solutions, but also social, environmental, and organizational innovations. The area of their operation is the implementation of virtual processes in the environment of extensive ICT networks (their technological platform of choice is most frequently the Internet), aimed at the coordination and integration of many, often very diverse business partners in their supply chain [54].

These types of entities are of particular value to their environment (e.g., to the EU and its goals of sustainable development) as they navigate the environment wisely, avoiding defeats and achieving relatively numerous successes. The achievement of the assumed objectives is accomplished, in their case by generating and selecting information from their own (and other entities') experience, which is transformed into professional knowledge and the ability to use it efficiently. These actors have a particular ability for continuous learning as they have the ability to create, acquire, organize, sustain, and share knowledge as well as use it to modify their organizational behavior. In addition to learning processes and the systematic collection and processing of data and information into useful knowledge, they are also able, through the definition and implementation of appropriate internal structures, to create appropriate conditions for the dissemination and use of the knowledge thus accumulated. An intelligent organization seen in this way (smart) can be seen as a metaphor, an endless process of organizational improvement of structure and method of operation, realized through methodical gaining and applying knowledge in order to survive and further develop in a sustainable manner [21,55].

Some also view smart and sustainable organizations as examples of business networking, understood as one of the most important abilities that will be demanded of businesses in the Age of Industry 4.0. This is because a smart organization operates in a self-made "knowledge environment", an infosphere that exceeds its purely technical activity. The concept of an infosphere can be understood as a certain collection of ICT equipment, software, and human capital as well as structural data and information that can be directly accessed by people in their working environments [55]. In this way, smart, as an attribute, stems from the manner in which the organization develops and uses knowledge as an integrated resource, combining the expertise of its human force, environmental sustainability, and the support offered by the technological platform it uses [40]. As a result, the productivity growth of smart organizations is a consequence of the organizational changes enabled 
by technological innovation, not the technologies themselves, and will only be achieved by organizations that adopt new forms of work, along with new technologies [56,57]. Advanced technologies used by organizations also provide the potential to build new relationships, organizational forms, and new experiences on a wider scale. Products and services equipped with smart technologies offer innovative features that transform their design, manufacture, delivery, and use. As seen above, organizational sustainability is closely linked to smartness. According to the original definition of sustainability, it is "the process of meeting the developmental aspirations of the present generation in such a way that the same aspirations can be fulfilled by future generations" [58,59]. In the environmental context, its main premise is to warn against the increasing exploitation of natural resources under pressure from the intensification of economic processes. Nowadays, however, the prevailing view is that the concept of "sustainability" has a broader dimension and refers not only to environmental aspects, but also to economic, social, and spatial ones in the context of the functioning of various organizations. It can therefore be assumed that it is a process that ensures high ecological, economic, social, and spatial standards for all currently cooperating entities, as well as all future generations, in accordance with the principles of intra- and inter-generational equity. A similar definition has been formulated by the UN World Commission on Environment and Development, which states that sustainable development is "development that meets the needs of the present without compromising the ability of future generations to meet their own needs" [59].

From an organization's perspective, however, it is assumed that the long-term prosperity of a company depends on paying attention to the three aspects of sustainability: social, environmental, and economic. Therefore, if sustainable development of a smart organization depends on its interdependence within the three subsystems-environmental, economic and social - then the effective management of such an organization must be reflected in appropriate conditions for the proper and sustainable use of its potential resources, skills, and relationships. It is widely accepted that advanced technologies including ICTs have a positive impact on the environment (e.g., through the reduction of greenhouse gases (GHG) or through the application of smart or robotic solutions and production optimization in various sectors such as manufacturing, energy, and agriculture, improving energy efficiency). They can also be used to support the achievement of sustainability and environmental goals by supporting the flow of information in production processes [60].

Advanced technologies are also linked to social sustainability, both from a micro and macro perspective. From an organizational standpoint, the use of advanced technologies improves ergonomics, worker safety, and facilitates risk assessment [61]. On the other hand, from a macro perspective, a link can be seen between the incorporation of advanced technologies in product manufacturing and modeling, transforming digital designs into physical objects without the need for tools, and sustainable social outcomes such as equivalent opportunities for all parties in societies and markets, user-oriented goods and services, increased customer value, possible health benefits for workers/people, and an impact on the industrial work situation [62].

Sustainability skills and environmental awareness are now a priority for many smart/intelligent organizations, both in the private and public sectors, and are also key features of sustainable organizations. Their common response to changes in their environment is to implement innovative, sustainable processes in order to have a positive impact on the environment as well as to create robust social, relational, and financial capital. In this way, smart and sustainable organizations are not only able to meet their own objectives, but are also prepared to meet more ambitious, often social or environmental challenges. Currently, the objectives of the Agenda for Sustainable Development of the EU are key in this respect [63]. They signal the need to fight poverty, raise the quality of life, and care for the environment. More and more often, smart and sustainable organizations are not only technologically or relationally developed, but also strongly involved in CSR and environmental activities including renewable energy investments. 


\subsection{Problem Definition}

In this paper, the key variables of smart organization IR 4.0 were identified, modeled, and analyzed. Bearing in mind the above considerations, the following hypotheses were made, as shown in Figure 1.

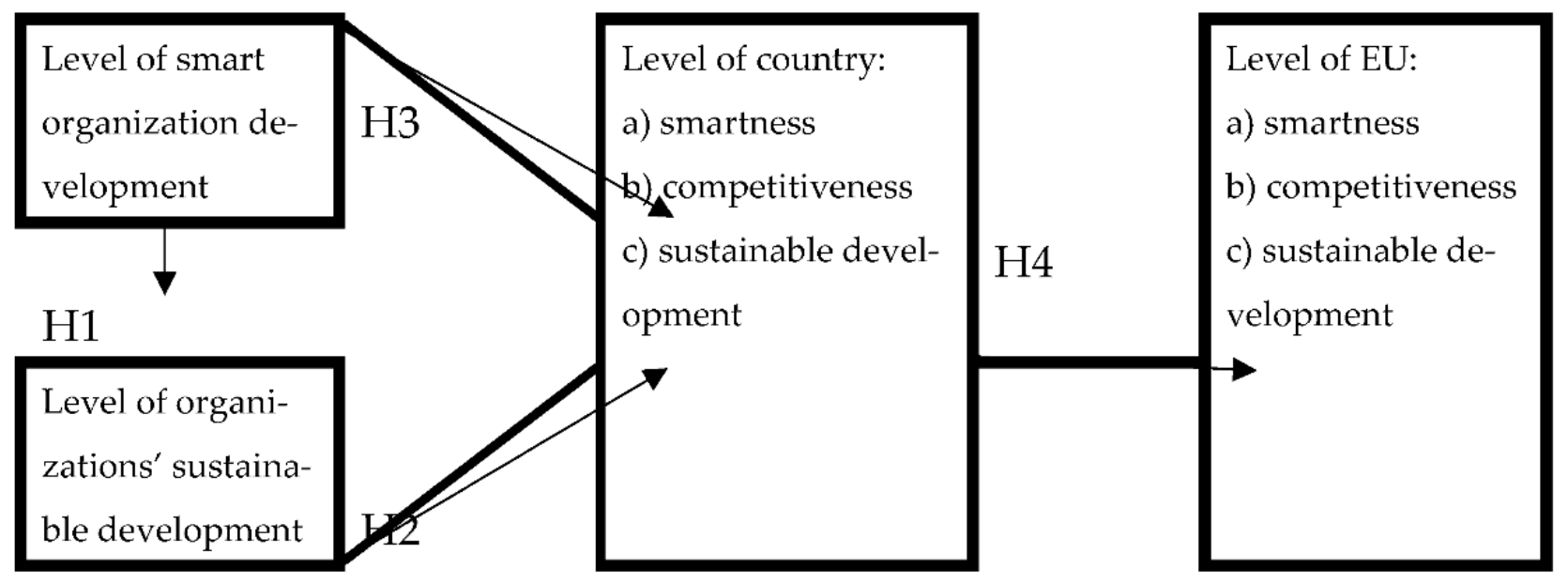

Figure 1. Hypotheses.

Hypothesis 1 (H1). There is a positive relationship between the level of smart organization development and the degree of sustainable development strategy implementation in EU countries.

Hypothesis 2 (H2). There is a positive relationship between companies' attitudes toward sustainable development and the level of competitiveness and sustainability in EU countries.

Hypothesis 3 (H3). There is a positive relationship between the level of smart organizations' development and the level of (a) smartness, (b) competitiveness, and (c) sustainable development in EU countries.

Hypothesis 4 (H4). The smartness of particular EU countries determines the smartness, competitiveness, and sustainability of Europe as a whole.

\subsection{Research Objectives}

The paper focused on studying the concept of "smart organization" and providing a map for the usage of various factors as sources of smart organization development in the smart and sustainable EU in the Industry 4.0 era.

Its objectives are as follows:

1. To identify and evaluate the use of crucial factors of "power of smart organization" in smart and sustainable EU IR 4.0,

2. To indicate paths for more effective EU navigation toward smart and sustainable EU IR 4.0. based on power of smart organizations.

The following research questions have been formulated for the purposes set out above:

Q1. What is the uniqueness and "power" of smart organizations?

Q2. What are the main benefits of building strong smart organizations?

Q3. How can the "power" of smart organizations in a country be monitored?

Q4. How does the development and use of the "power" of smart organizations in the EU look like?

Q5. How smart organizations can support sustainable development of EU?

For this purpose, the Power of Smart Organization Index and roadmap of smart and sustainable EU were constructed. Answering the above research questions and verifying 
the hypotheses will allow the integration of the micro and macro perspective and will be a contribution to research on the value of smart and sustainable organizations.

\section{Identification of Possible Sources of Power for Smart Organization IR 4.0}

An intelligent/smart organization is an economic system that effectively uses a considerable number of special, new IR 4.0 technologies (e.g., ICT) as well as organizational and human knowledge and competencies (see the collection in Figure 2, column 1). In this way, it is a type of organization, in which people and machines interact in technologically dense environments [64], thus enacting what has been called "sociomateriality" [65].

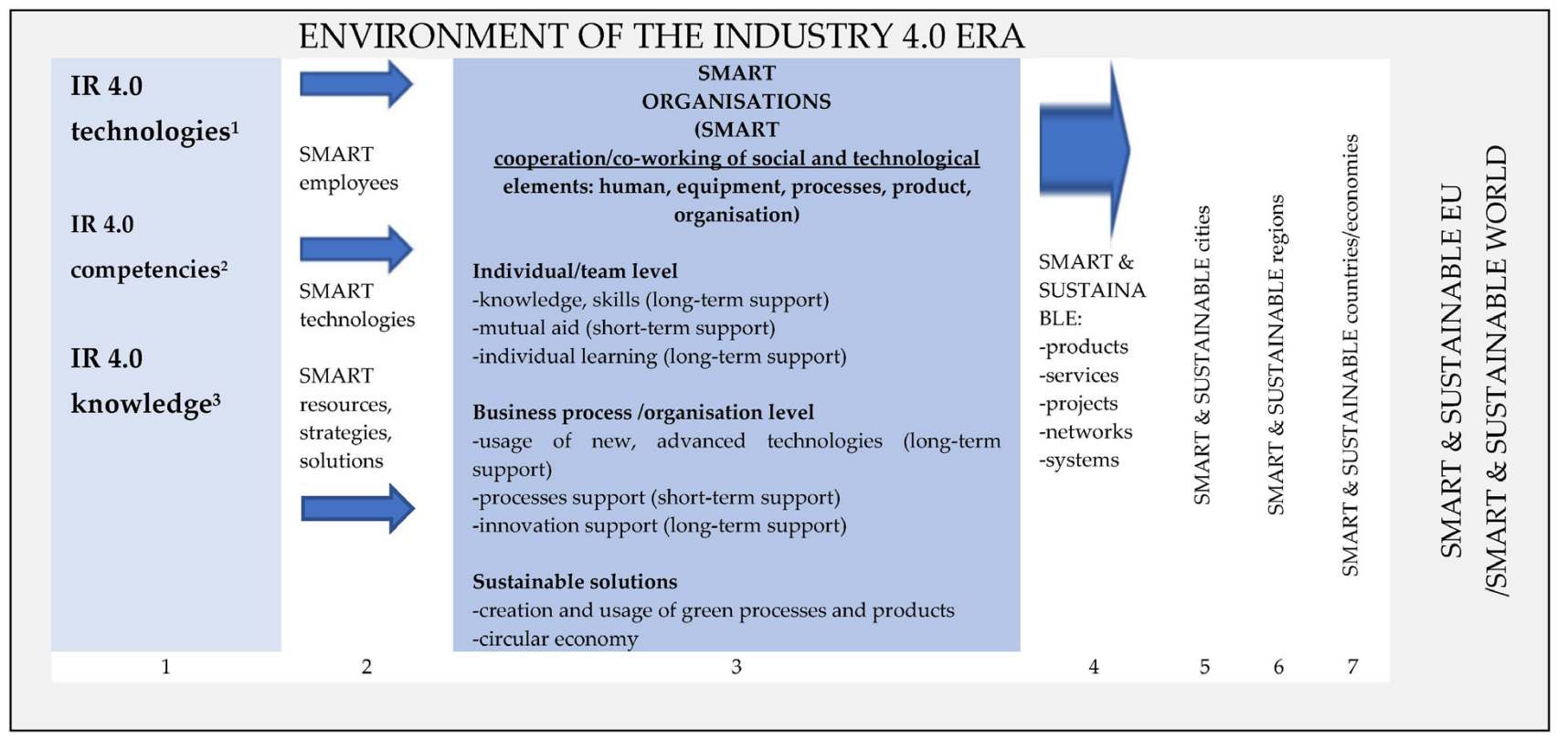

Figure 2. Smart organizations in the SMART and SUSTAINABLE EU/SMART and SUSTAINABLE WORLD ${ }^{1}$ ICT: technologies used for digitization, simulation, and forecasting, integrated software, machine to machine communication (M2M), cloud computing, innovative methods for collection and processing big data, cybersecurity, cyber-physical systems (CPS), Internet of Services (IoS), Internet of Things (IoT); advanced technologies: virtual reality (VR), augmented reality (AR), digital twins, neural networks (NN), mass customization; artificial intelligence (AI), autonomous robots (AR); ${ }^{2}$ competencies: substantive knowledge, ability to learn, ability to work as a team; ability to work in a multicultural environment; ability to work remotely; knowledge of foreign languages and IT; ability to share knowledge; attitudes: the desire for continuous development, goal orientation, openness to new experiences, creativity, flexible thinking, agility, high tolerance of uncertainty, social responsibility; ${ }^{3}$ about: key resources: knowledge, employees, dynamic skills, relations, new technologies; strategies for development and competitiveness: varied, proactive, agile, innovative, flexible, dynamic; advantage-building strategies: qualitative, dispersed, intangible, non-realistic, unstable, synergy-oriented; modern functional strategies: HRM, logistic, marketing, production, financial, etc.; about key solutions:-relational strategies based on strategic partnership, cooperation, networking, alliances, sharing economy (C2C, B2C, B2B), co-creation, ambidexterity; management strategy: knowledge-based (Knowledge Partnering, Open Knowledge), innovation-based (Open Innovation), resource-based (Open Resources); service and customer orientation; leading structural solutions, corporate social responsibility of the organizations: decentralization of power; horizontal and flexible organizational structures; dominance of horizontal communication; organic model; cultural openness; empowerment; work in creative tasks and project teams; quick decision-making process; short communication channels, knowledge sharing between departments; recommended structures: networks, matrices, hybrid, based on teams.

In this way, smart and sustainable organizations, on one hand, accumulate what is most valuable in a given region and, on the other, distribute their achievements by means of their activity, through which they determine and support the pace of development of their environment (i.e., also cities, regions, or countries/economies from which they originate and in which they operate, Figure 2, columns 5,6,7). They become not only stimulators, 
but even a "source" of competitiveness, sustainability, and catalysts of the fulfilment of goals of the sustainable development of EU. Thus, smart organizations are organizations with the capacity for creating, acquiring, classifying, and sharing knowledge as well as applying it to increase their global market effectiveness and competitiveness [39,51]. Their strength determines the implementation of the key contemporary objectives of sustainable development of the world in Age of IR 4.0 (Smart World IR 4.0). They are the blueprints to achieving a better and more sustainable future for all and address the global challenges we are facing and that we should achieve by 2030. For a more complete exploitation of their possibilities, it is necessary to understand the specificity of crucial sources of their "power", related to both technical and social aspects. These observations above seem to answer the first two research questions (Q1-Q2).

\subsection{A Brief Description of the Crucial Technological Sources of Power of Smart Organization IR 4.0}

\subsubsection{Integrated Software}

A tightly interconnected suite of several applications that share a common database and user interface. In practice, it is a web of complex software applications that handle tasks such as accounting, financial consolidation, and inventory management. This is a type of organization architecture. When analyzed using advanced algorithms, such information can, for example, help managers in understanding how to earn customer loyalty, develop marketing campaigns, improve their products, and provide services tailormade to the preferences and needs of their customers. The knowledge of such preferences may allow entrepreneurs to craft content that will be able to satisfy them. The key purpose of employing such analytical solutions in organizations is thus to make good decisions according to up-to-date and aggregated data [52,66,67].

\subsubsection{Innovative Methods of Big Data Collection and Processing}

Big data processing uses analytical tools or programming models to use large-scale data to bring out information useful for support and decision-making. Big datasets are typically stored in a large number of commodity servers, so conventional software tools such as message passing interface (MPI) cannot manage them successfully [66-68].

\subsubsection{Internet of Things (IoT)}

The IoT is a dynamic global "network of physical objects, systems, platforms, and applications" that are capable of communicating and sharing intelligence among themselves, their external environment, and people. The IoT, thanks to its individual identification system, enables "things" — such as RFID (Radio-Frequency Identification) tags, sensors, and actuators-to interact and collaborate with each other to achieve common goals. Three characteristics that distinguish the Internet of Things are context, ubiquity, and optimization. This leads directly to the creation of new and improved products (services), enabling a visible jump in economic productivity [69-73]. The Internet of Services, or IoS, "is part of the Internet, which represents services and their functionality as components provided by different providers, available for use on request and characterized by the possibility of mutual integration. IoS is used to flexibly build value networks by dynamically configuring services selected from various resources available in the network" [74,75].

\subsubsection{Cyber-Physical Systems (CPS)}

Cyber-physical systems are "a combination of the computing layer and physical processes ... most often in the form of embedded systems and networks for monitoring and controlling physical processes. They allow collecting, processing, and influencing the physical processes of production of personalized products with a reduced human contribution. Thanks to them, the production process control system operates in a feedback loop. In this case, the physical processes are the data source for calculating the control signal of the selected executables." [72,75-78]. 


\subsubsection{Cloud Computing (CC)}

Cloud computing is "the delivery of different services through the Internet. These resources include tools and applications like data storage, servers, databases, networking, and software; it is a model allowing access through the network to computing resources that can be provided and based on the use of services provided by an internal or external service provider" [79]. A component of cloud computing is cloud-based manufacturing (CMB), which can be described as a networked model of a production system that, from its diverse and distributed production resources, creates temporary, reconfigurable cyber-physical production lines. The use of network models enables the allocation of production resources in response to the customer's request, which contributes to increased productivity and reduces the cost of product life $[80,81]$. By using tools available in a cloud, organizations are able to reduce ICT costs, break geographic barriers, and gain access to data at any time and place. A cloud is a factor that puts other SMAC components together [52].

\subsubsection{Neural Networks (NN)}

Neural networks are a collection of algorithms that are loosely modeled on the human brain. They are mainly employed for pattern recognition, performed by interpreting data obtained from various sensors using a kind of machine perception, labelling, or clustering of raw input. Such patterns are numerical and vector-based, so real-world data such as images, sound, text, or time series have to first be translated into numbers. Neural networks are thus useful in cluster and classifying data in applications such as almost realtime language translation. Overcoming the language barriers may open a new age in global business relations including the implementation of highly efficient and fast operations by globally connected enterprises [82,83].

\subsubsection{Direct Communication between Machines (M2M)}

Direct communication between machines is the technology connecting machines at a distance from each other by using ICT; most of these connections are controlled by software. The machines communicate between them (and their users) remotely. Hence, the process (and the machines themselves) can be managed from anywhere. The structure of M2M networks resemble LAN or WAN layouts, which is why the name Internet of Things is frequently used to describe them. They are, however, exclusively used to provide a communication protocol to machines, sensors, and controllers. Devices connected in this way are able to send the information they collect to other devices in the network, which in turn allows the user to assess the state of the whole network and react accordingly by sending commands to such networked devices [84-87].

\subsubsection{Cybersecurity}

Cybersecurity is the practice of securing systems, networks, and software applications from digital attacks, usually meant to access, alter, or destroy sensitive information; extort money from users; or interrupt their business processes. In order to work properly, a cybersecurity solution has to comprise a system of multiple layers of protection across the computers, networks, applications, or data that require safe keeping. In an organization, effective defense against such attacks also involves the cooperation between people, processes, and technology [88,89].

\subsubsection{Artificial Intelligence (AI)}

Artificial Intelligence is the ability of a digital computer or computer-controlled robot to perform tasks commonly associated with sentient beings. The term is used in reference to systems developed to exhibit intellectual processes characteristic of humans such as reasoning, discovering meaning, generalizing, or learning from past experience. There are already applications that may be said to be on par with human experts and professionals when performing certain tasks. In this limited sense, artificial intelligence may be found 
in applications such as medical diagnostics, search engines, and voice or handwriting recognition $[90,91]$.

\subsubsection{Digitization, Digitalization}

Digitization, or digitalization, essentially refers to taking analogue information and encoding it into zeroes and ones so that computers can store, process, and transmit such information; hence, it is the way in which many domains of social life are restructured around digital communication and media infrastructures, and how people interact. "Digitalization is the use of digital technologies to change a business model and provide new revenue and value-producing opportunities." It is the process of moving to a digital business by employing digital technologies and information to transform business operations [92-95].

\subsection{Brief Description of Crucial Social Sources of Power in Smart or Ganizations IR 4.0}

\subsubsection{Ability to Work Remotely}

The term "remote work" simply means any work that does not require an employee to commute to an office. Remote work thus means professional duties performed from home or any location outside of formal employer's premises (such as a café or a co-working space) on a full-time or near full-time basis (four or more days a week), very often [55,96,97]. The increasing prevalence of full-time remote work is changing the dynamics in local contexts and creates new paths in regional development [98].

\subsubsection{Knowledge of Foreign Languages}

As the global business environment is getting increasingly integrated, the ability to communicate in multiple languages becomes a necessity as forging lasting, stable international business relationships often starts with direct communication in the client's native language. Thus, any multilingual person has an automatic advantage over their peers when competing for jobs and promotions to higher positions. Globalization has given rise to the creation of global teams. These global teams (GVT) operate in a globally dispersed work environment, and are characterized by a high degree of heterogeneity in multiple dimensions including the nationality of members, geographical location, and languages spoken; differences in linguistic capabilities can influence the effectiveness of knowledge sharing and cognitive resources can be easily depleted because of foreign language anxiety, which in turn can negatively influence effectiveness when performing tasks as well as personal and organizational development [99,100].

\subsubsection{Individual Usage of the Internet}

Internet access improves opportunities for education, employment, governance, and social life. Studies have shown that demographic attributes influence an individuals' actions even before they engage in a given behavior. Gender, age, and income are amongst the significant determinants of Internet usage [101]. The influence of Internet usage on workers' well-being is four-fold. First, it provides users with unprecedented access to data and information. Second, Internet technologies have resulted in the creation of new activities and services, and, consequently, brand-new occupations that widen the employment perspectives of skilled workers. Third, Internet use in a professional environment may be a way to save time, with employees performing time-consuming and repetitive tasks in a more efficient way. Finally, the Internet is cheap and simple long-distance communication between employees has become viable. This in turn provides brand new methods of internal communication and leadership as well as facilitate information flow between managers and employees [102].

\subsubsection{Openness to New Experiences}

Human psychological traits influence success and long-lasting action in extreme situations [103]. With a rapid increase in the amount of knowledge that is the keystone of the information era, openness is crucial for an organization to survive and maintain its 
competitive advantage. Such openness is also positively related to employee creativity as employees open to new experiences are more creative when their leaders' expectations of creativity are high [104].

\subsubsection{Ability to Share Knowledge}

Knowledge sharing among employees is a function of their motivation, opportunity, and ability (MOA) to do so. The interaction among motivation, opportunity, and ability drives knowledge-sharing behavior. It forms a dynamic and coordinated system that should be considered and analyzed as such [105]. Knowledge sharing means the provision of information and know-how to help others perform their tasks and collaborate on solving problems, new ideas, or implementing policies and procedures. Knowledge sharing is vital for an organization to develop its competitive advantage, and it is an integral part of the knowledge management process [106-110].

\subsubsection{Possession of IT Knowledge}

As information and communication technologies (ICTs) are becoming ubiquitous, new activities, opportunities, and resources for learning emerge, while the learning potential of traditional contexts such as family, schools, and companies is also expanding. Knowledge and practical skills in this scope including computer literacy, the use and development of the latest software, applications, systems, and accompanying devices, serve as a ladder to professional, market, and even social success [111-113].

\subsubsection{Ability to Learn the Desire for Continuous Development, Lifelong Learning}

The ability to learn and the desire for continuous development and lifelong learning has three dimensions: (1) vertical education is primarily school education, covering levels from kindergarten to university (including postgraduate studies); (2) horizontal education takes place in extracurricular educational institutions and also serves cultural education; and (3) in-depth education is a lifestyle (including leisure activities) associated with lifelong learning. The idea of lifelong learning therefore means maintaining the continuity and regularity of the learning process, but it also indicates the multidimensionality and versatility of learning $[114,115]$.

\subsubsection{Possession of Substantive Knowledge}

Possession of substantive knowledge refers to knowledge developed by people in academic communities. Substantive knowledge is the content that teachers communicate as ascertained fact, whether common conception or reasonable grasp of reality $[116,117]$.

\subsubsection{Creativity}

Creativity is the ability to produce original and unusual ideas or to make something new or innovative. Creativity is characterized by the ability to perceive the world in new ways, find hidden patterns, make relationships between apparently unrelated aspects, and find solutions. Creativity covers two processes: thinking and then producing. "Creativity is a combinatorial force: it is our ability to tap into our 'inner' pool of resources-knowledge, insight, information, inspiration, and all the fragments populating our minds-that we have accumulated over the years just by being present and alive and awake to the world, and to combine them in extraordinary new ways" [118-120].

\subsubsection{Work in Partnership (Teamwork)}

Working in teams is meant as a means for employees to cover for one another and provide consistent, continuous support, share information they may need, develop ideas together as well as combine their respective skills and knowledge. Teamwork provides groups of individuals with diverse skills and talents with an opportunity work together to achieve a common goal. Working with teammates, sharing ideas, improving the work of others, and helping one another to form a good team is thus crucial [108]. It is also 
important to form close relations with new and existing partners to be able to overcome challenges and reconcile interests. The development of partnerships should be promoted among different participants to increase the amount of collective knowledge, test ideas, and expand dialogue [121].

\section{Methods and Test Results}

In order to achieve the research objectives and answers to Q3-Q5, a synthetic Power of Smart Organizations Index (PSOI) was developed. In the first step of its construction, based on a review of the world literature on the issue (Section 1) and expert research (interviews were conducted with 10 experts who are members of the international OPI 4.0 Research Group initiated by the employees of the Lodz University of Technology and operating on the ResearchGate platform), 10 technical and 10 social factors characterizing the way smart organizations operate in the IR 4.0 age were isolated. Their synthetic description is presented above (Section 2). In order to establish their real role in the smart EU competitiveness and sustainable development processes, the next step was to find their practical counterparts in the form of detailed indicators regularly reported by Eurostat. The final selection of indicators was based on their availability in all countries and years surveyed. The result of these activities is presented in Table 2, which is a summary of the sub-variables ultimately used to build the synthetic PSOI.

Table 2. Indicators of organizational smartness.

\begin{tabular}{|c|c|c|c|}
\hline Technological Indicators (T) & & Social Indicators (S) & \\
\hline $\begin{array}{l}\text { Enterprises whose business processes } \\
\text { are automatically linked to those of } \\
\text { their suppliers and/or customers (\%) }\end{array}$ & $\mathrm{T} 1$ & $\begin{array}{l}\text { Individuals with broadband access to } \\
\text { the Internet }(\%)\end{array}$ & S1 \\
\hline Enterprises with Big Data analysis (\%) & $\mathrm{T} 2$ & $\begin{array}{l}\text { Individuals in science and } \\
\text { technology }(\%)\end{array}$ & $\mathrm{S} 2$ \\
\hline $\begin{array}{c}\text { Enterprises with broadband access to } \\
\text { the Internet (\%) }\end{array}$ & $\mathrm{T} 3$ & $\begin{array}{l}\text { Employees using computers with } \\
\text { access to the Internet }(\%)\end{array}$ & S3 \\
\hline $\begin{array}{l}\text { Enterprises with integration of } \\
\text { internal processes }(\%)\end{array}$ & $\mathrm{T} 4$ & $\begin{array}{l}\text { Individuals ordering or purchasing } \\
\text { goods or services over the Internet for } \\
\text { private use }(\%)\end{array}$ & S4 \\
\hline $\begin{array}{c}\text { Enterprises using cloud computing } \\
\text { services (\%) }\end{array}$ & $\mathrm{T} 5$ & $\begin{array}{l}\text { Individuals obtaining information } \\
\text { from websites of public authorities (\%) }\end{array}$ & S5 \\
\hline $\begin{array}{l}\text { Enterprises sending electronic invoices } \\
\text { suitable for automatic processing (\%) }\end{array}$ & T6 & $\begin{array}{l}\text { Students of information and } \\
\text { communication technologies as the } \\
\text { share of students in total (\%) }\end{array}$ & S6 \\
\hline $\begin{array}{l}\text { Enterprises providing portable devices } \\
\text { to the persons employed (\%) }\end{array}$ & $\mathrm{T} 7$ & $\begin{array}{l}\text { Adult learning and training in the last } \\
4 \text { weeks }(\%)\end{array}$ & S7 \\
\hline ICT risk assessments in enterprises (\%) & $\mathrm{T} 8$ & $\begin{array}{l}\text { Individuals with achievement in } \\
\text { reading, maths, or science }(\%)\end{array}$ & S8 \\
\hline $\begin{array}{l}\text { Enterprises that employ ICT } \\
\text { specialists (\%) }\end{array}$ & $\mathrm{T} 9$ & $\begin{array}{l}\text { Submitting completed forms, in \% of } \\
\text { total individuals }\end{array}$ & S9 \\
\hline $\begin{array}{l}\text { Enterprises with high and very high } \\
\text { level of the digital intensity index }(\%)\end{array}$ & $\mathrm{T} 10$ & Individuals use of cloud services (\%) & S10 \\
\hline
\end{tabular}

For the next step, data for the above sub-indicators were collected for the $28 \mathrm{EU}$ countries for the period 2018-2019 [122]. After they were systematized in the database and divided into two complementary partial dimensions - technological and social—individual sub-indicators were standardized with the following formula:

$$
z=\frac{x-\mu}{\delta}
$$


where

$z$ is the standardized sub-indicator;

$x$ is the variable for a specific country;

$\mu$ is the mean; and

$\delta$ is the standard deviation.

\subsection{Power of Smart Organizations Index (PSOI)—Basic Analysis}

For such isolated variables, a synthetic Power of Smart Organizations Index (PSOI) was constructed to accumulate the total power of their impact. For ease of analysis, it was assumed that the individual indicators were equivalent. It was therefore not necessary to rank them. To improve the readability of the index, two complementary dimensions were identified: the technological dimension of the Power of Smart Organizations Index/Technological (PSOI/T) and the social dimension of the Power of Smart Organizations Index/Social (PSOI/S) (all data were deposited in a repository: Sikora-Fernandez, Dorota (2020), "smart organizations in the EU-28", Mendeley Data, V1, doi:10.17632/9td5chzm5g.1, accessed on 15 June 2020). Overall PSOI RANK and partial PSOI/T RANK and PSOI/S RANK results are presented in Table 3.

Table 3. Power of Smart Organization ranks.

\begin{tabular}{|c|c|c|c|c|c|c|}
\hline & PSOI RANK & Result & PSOI/T RANK & Result & PSOI/S RANK & Result \\
\hline 1 & Finland & 31.99 & Finland & 17.90 & Denmark & 14.13 \\
\hline 2 & Denmark & 28.41 & Denmark & 14.28 & Finland & 14.09 \\
\hline 3 & Netherlands & 20.66 & Netherlands & 10.31 & Sweden & 13.96 \\
\hline 4 & Sweden & 20.50 & Belgium & 6.84 & Netherlands & 10.35 \\
\hline 5 & Ireland & 10.41 & Sweden & 6.55 & Estonia & 8.55 \\
\hline 6 & United Kingdom & 8.87 & Ireland & 3.62 & United Kingdom & 7.70 \\
\hline 7 & Belgium & 7.86 & Slovenia & 2.94 & Ireland & 6.79 \\
\hline 8 & Luxembourg & 6.38 & Malta & 2.15 & Luxembourg & 5.77 \\
\hline 9 & Estonia & 4.93 & Portugal & 1.84 & Germany & 3.14 \\
\hline 10 & Germany & 4.56 & Lithuania & 1.54 & Austria & 2.49 \\
\hline 11 & France & 3.55 & Germany & 1.41 & France & 2.18 \\
\hline 12 & Austria & 2.26 & France & 1.37 & Spain & 2.11 \\
\hline 13 & Spain & 1.94 & United Kingdom & 1.16 & Belgium & 1.02 \\
\hline 14 & Slovenia & 1.52 & Luxembourg & 0.62 & Slovenia & -1.42 \\
\hline 15 & Malta & 0.66 & Spain & -0.16 & Malta & -1.49 \\
\hline 16 & Lithuania & -1.74 & Austria & -0.23 & Latvia & -2.33 \\
\hline 17 & Czechia & -5.20 & Italy & -2.18 & Hungary & -2.89 \\
\hline 18 & Portugal & -5.51 & Czechia & -2.25 & Czechia & -2.95 \\
\hline 19 & Cyprus & -8.05 & Cyprus & -2.77 & Lithuania & -3.28 \\
\hline 20 & Poland & -8.15 & Poland & -3.09 & Poland & -5.07 \\
\hline 21 & Latvia & -9.63 & Estonia & -3.61 & Cyprus & -5.28 \\
\hline 22 & Italy & -10.16 & Croatia & -3.93 & Slovakia & -7.02 \\
\hline 23 & Croatia & -11.61 & Slovakia & -5.06 & Portugal & -7.35 \\
\hline 24 & Slovakia & -12.07 & Latvia & -7.30 & Croatia & -7.67 \\
\hline 25 & Hungary & -14.42 & Greece & -8.94 & Italy & -7.99 \\
\hline 26 & Greece & -17.97 & Bulgaria & -10.42 & Greece & -9.03 \\
\hline 27 & Romania & -25.81 & Hungary & -11.53 & Romania & -12.76 \\
\hline 28 & Bulgaria & -27.64 & Romania & -13.05 & Bulgaria & -17.23 \\
\hline
\end{tabular}

Source: Own elaboration.

In the next step, the results of the studies (PSOI RANK) were compared with the current EU Competitiveness Reports and The Leaving-No-One-Behind Report [123].

\subsection{Power of Smart Organizations Index (PSOI)—Comparative Analysis}

In the next step, the results of the studies (PSOI RANK) (graphical representation of the test results is shown in Figure 3) were compared with the current EU Competitiveness Reports and The Leaving-No-One-Behind Report. 

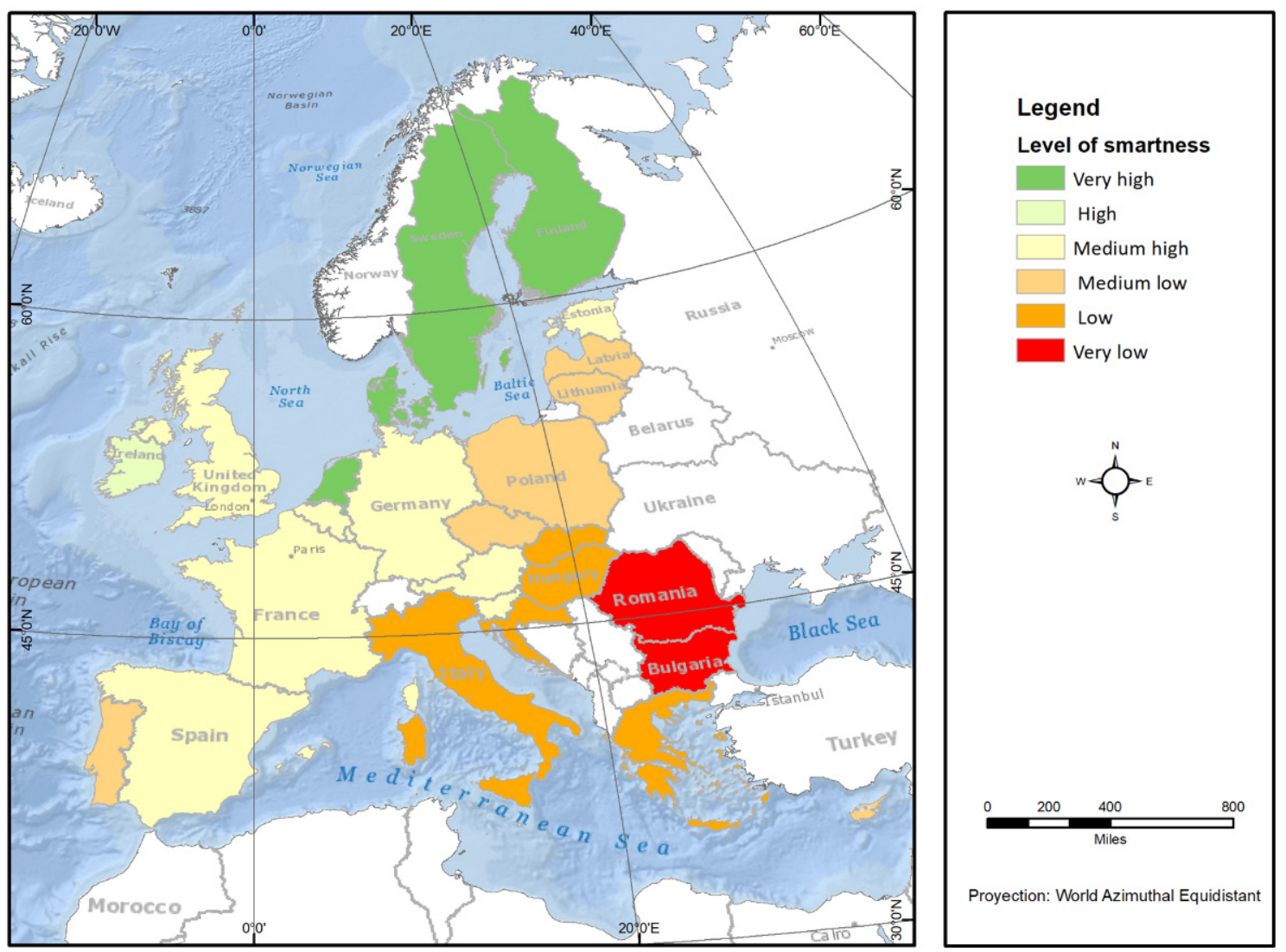

Figure 3. Level of EU smartness.

Comparing the level of smart (smartness) of organizations in individual EU countries (PSOI RANK) with the level of their competitiveness and sustainability in several reports, it can be seen that the PSOI confirms the trends visible, among others, in the Europe 2020 Competence Report and in the report "The EU Regional Competitiveness Index 2019" [124,125] as well as in the Europe Sustainable Report [124].

As can be seen from the above summaries, the smartness of organizations in the Age of Industry 4.0 is crucial for the actual sustainability of a country, which in turn has a major impact on the competitiveness of this country. However, it is important not only to have the right technologies and skills, but also the adequate level of their development and use. The achievements of countries with very high levels of development of smart organizations (PSOI results rank 1-5, Table 4) signal the importance of the need for balanced and high development in both technological and social dimensions. The positions of other countries are the consequences, on one hand, of uneven development (PSOI results rank 6-16, Table 4) and, on the other, weak development in both dimensions (PSOI results rank 17-28, Table 4).

In light of the confirmation of the association of the smartness of organizations and sustainability and competitiveness of countries, analyses were undertaken to deepen the factors generating the high level of EU smartness (Table 4, column 4). The research was conducted in several stages. It was decided at the outset to determine the current state of development of the EU smartness generating factors, and in the next step, to determine the desired state and possible paths to its achievement. 
Table 4. EU smartness vs. competitiveness vs. sustainability.

\begin{tabular}{|c|c|c|c|c|c|c|c|c|}
\hline & PSOI RANK & Result & $\begin{array}{l}\text { Level of } \\
\text { SMART }\end{array}$ & $\begin{array}{l}\text { PSOI/T } \\
\text { RANK }\end{array}$ & $\begin{array}{l}\text { PSOI/S } \\
\text { RANK }\end{array}$ & $\begin{array}{l}\text { Competitiveness } \\
\text { in EU RANK }\end{array}$ & $\begin{array}{c}2019 \\
\text { SDG/LNOB } \\
\text { Index Rank }\end{array}$ & $\begin{array}{c}2020 \\
\text { SDG/LNOB } \\
\text { Index Rank }\end{array}$ \\
\hline 1 & Finland & 31.98 & & 1 & 2 & 6 & $3 / 1$ & $\frac{1}{2}$ \\
\hline 2 & Denmark & 28.41 & $20-\ldots$ & 2 & 1 & 5 & $1 / 3$ & $3 / 6$ \\
\hline 3 & Netherlands & 20.65 & very high & 3 & 4 & 1 & $7 / 2$ & $14 / 4$ \\
\hline 4 & Sweden & 20.50 & & 5 & 3 & 3 & $2 / 4$ & $2 / 5$ \\
\hline 5 & Ireland & 10.40 & 10-20 high & 6 & 7 & 12 & $13 / 10$ & $18 / 14$ \\
\hline 6 & United Kingdom & 8.86 & & 13 & 6 & 4 & $12 / 8$ & $15 / 12$ \\
\hline 7 & Belgium & 7.86 & & 4 & 13 & 10 & $11 / 12$ & $13 / 13$ \\
\hline 8 & Luxembourg & 6.38 & & 14 & 8 & 8 & $17 / 11$ & $26 / 16$ \\
\hline 9 & Estonia & 4.93 & & 21 & 5 & 14 & $10 / 15$ & $12 / 18$ \\
\hline 10 & Germany & 4.55 & 0-10 & 11 & 9 & 2 & $5 / 7$ & $6 / 11$ \\
\hline 11 & France & 3.54 & medium high & 12 & 11 & 7 & $6 / 9$ & $9 / 10$ \\
\hline 12 & Austria & 2.25 & & 16 & 10 & 9 & $4 / 6$ & $4 / 8$ \\
\hline 13 & Spain & 1.94 & & 15 & 12 & 11 & $14 / 14$ & $21 / 15$ \\
\hline 14 & Slovenia & 1.51 & & 7 & 14 & 17 & $9 / 5$ & $7 / 9$ \\
\hline 15 & Malta & 0.65 & & 8 & 15 & 19 & $24 / 17$ & $27 / 22$ \\
\hline 16 & Lithuania & -1.73 & & 10 & 19 & 20 & $23 / 24$ & $25 / 25$ \\
\hline 17 & Czech & -5.19 & & 18 & 18 & 15 & $8 / 13$ & $10 / 17$ \\
\hline 18 & Portugal & -5.51 & $0-(-10)$ & 9 & 23 & 16 & $15 / 20$ & $22 / 24$ \\
\hline 19 & Cyprus & -8.04 & medium low & 19 & 21 & 23 & $28 / 25$ & $29 / 28$ \\
\hline 20 & Poland & -8.15 & & 20 & 20 & 18 & $16 / 16$ & $16 / 19$ \\
\hline 21 & Latvia & -9.63 & & 24 & 16 & 21 & $20 / 21$ & $20 / 26$ \\
\hline 22 & Italy & -10.16 & & 17 & 25 & 13 & $18 / 18$ & $23 / 20$ \\
\hline 23 & Croatia & -11.60 & & 22 & 24 & 28 & $22 / 22$ & $24 / 21$ \\
\hline 24 & Slovakia & -12.07 & $(-10)-(-20)$ & 23 & 22 & 22 & $19 / 19$ & $17 / 23$ \\
\hline 25 & Hungary & -14.42 & low & 27 & 17 & 24 & $21 / 23$ & $19 / 27$ \\
\hline 26 & Greece & -17.97 & & 25 & 26 & 27 & $25 / 26$ & $28 / 29$ \\
\hline 27 & Romania & -25.80 & $(-20)-$ & 28 & 27 & 26 & $27 / 28$ & $30 / 31$ \\
\hline 28 & Bulgaria & -27.64 & $\ldots$../very low & 26 & 28 & 25 & $26 / 27$ & $31 / 30$ \\
\hline
\end{tabular}

Source: Own elaboration.

\subsection{Power of Smart Organizations Index (PSOI)—In-Depth Analysis}

In order to implement the first stage of in-depth analysis, an attempt was made to establish five crucial factors of smart and sustainable organization in all EU countries examined, identifying those with the highest overall values. This procedure was aimed at isolating the "five crucial factors" most relevant to the construction of Smart EU 4.0. These are summarized in Table 5.

This analysis made it possible to determine which of the factors were most common in the EU countries studied and to obtain an EU mean result. The number of indications for individual factors is, in the authors' opinion, an indicator of their current role and strength in the process of building smart and sustainable EU 4.0 (Table 5, column 8). Particularly important catalysts for smartness, competitiveness, and sustainable development of EU have proven to be enterprises with the following: broadband access to the Internet (T3), ICT risk assessments (T8), business processes automatically linked to those of their suppliers and/or customers (T1), ICT specialists employed (T9), and integration of internal processes (T4). Table 5 therefore illustrates the current state of development of smart EU 4.0. However, it is not fully satisfactory, as it is distorted by data from economically weaker and less market-competitive EU Member States (the BOTTOM 10). 
Table 5. The "crucial five" indicators for Smart EU IR 4.0.

\begin{tabular}{|c|c|c|c|c|c|c|c|}
\hline \multicolumn{6}{|c|}{ The "Crucial Five" for Smart EU IR 4.0 } & \multirow{2}{*}{$\frac{\text { Rank }}{1}$} & \multirow{2}{*}{$\begin{array}{c}\text { Indicator } \\
\text { T3 (12) }\end{array}$} \\
\hline Finland & T3 & T5 & T6 & T8 & T9 & & \\
\hline Denmark & T3 & $\mathrm{T} 4$ & $\mathrm{~T} 7$ & $\mathrm{~T} 10$ & S3 & 2 & T8 (11) \\
\hline Netherlands & T3 & S1 & S5 & $\mathrm{S} 4$ & $\mathrm{~T} 8$ & 3 & T1 (10) \\
\hline Sweden & S7 & S10 & S9 & S3 & $\mathrm{T} 10$ & 4 & T9 (10) \\
\hline Ireland & S8 & $\mathrm{T} 8$ & $\mathrm{~T} 2$ & T5 & T9 & 5 & $\mathrm{~T} 4(9)$ \\
\hline United Kingdom & T9 & T10 & S1 & $\mathrm{S} 2$ & $\mathrm{~S} 4$ & 6 & T10 (8) \\
\hline Belgium & $\mathrm{T} 1$ & $\mathrm{~T} 2$ & T3 & $\mathrm{T} 4$ & $\mathrm{~T} 10$ & 7 & S6 (8) \\
\hline Luxembourg & $\mathrm{S} 2$ & S1 & S4 & S7 & $\mathrm{S} 10$ & 8 & S8 (8) \\
\hline Estonia & S5 & S6 & S7 & S8 & S9 & 9 & T7 (9) \\
\hline Germany & $\mathrm{T} 1$ & S4 & S5 & S6 & $\mathrm{T} 7$ & 10 & S1 (7) \\
\hline France & T3 & $\mathrm{T} 4$ & $\mathrm{~T} 7$ & S3 & S7 & 11 & T2 (6) \\
\hline Austria & $\mathrm{T} 7$ & S5 & $\mathrm{T} 4$ & S3 & S9 & 12 & T6 (6) \\
\hline Spain & T6 & S8 & $\mathrm{T} 4$ & $\mathrm{~S} 1$ & S10 & 13 & S3 (6) \\
\hline Slovenia & T6 & T9 & $\mathrm{T} 10$ & T3 & S8 & 14 & S4 (6) \\
\hline Malta & $\mathrm{T} 2$ & $\mathrm{~T} 8$ & T9 & S6 & $\mathrm{T} 10$ & 15 & S5 (6) \\
\hline Lithuania & $\mathrm{T} 1$ & $\mathrm{~T} 4$ & $\mathrm{~T} 10$ & T3 & $\mathrm{T} 4$ & 16 & S9 (6) \\
\hline Czech & S6 & $\mathrm{T} 8$ & $\mathrm{~T} 3$ & $\mathrm{~T} 4$ & T9 & 17 & S2(5) \\
\hline Portugal & T8 & T9 & $\mathrm{T} 1$ & $\mathrm{~T} 4$ & T3 & 18 & S7 (5) \\
\hline Cyprus & T9 & S1 & $\mathrm{S} 2$ & S10 & $\mathrm{T} 1$ & 19 & S10 (4) \\
\hline Poland & $\mathrm{T} 7$ & S8 & $\mathrm{T} 1$ & S6 & T9 & 20 & T5 (3) \\
\hline Latvia & T3 & S6 & S2 & S8 & S9 & & \\
\hline Italy & T6 & S7 & $\mathrm{T} 8$ & $\mathrm{~T} 3$ & $\mathrm{~T} 8$ & & \\
\hline Croatia & S8 & T9 & $\mathrm{T} 1$ & $\mathrm{~T} 5$ & $\mathrm{~T} 2$ & & \\
\hline Slovakia & $\mathrm{S} 4$ & T10 & $\mathrm{T} 1$ & $\mathrm{~T} 3$ & $\mathrm{~T} 8$ & & \\
\hline Hungary & S6 & S9 & S5 & $\mathrm{S} 1$ & S8 & & \\
\hline Greece & $\mathrm{S} 2$ & S4 & S5 & S9 & $\mathrm{T} 8$ & & \\
\hline Romania & S6 & $\mathrm{T} 7$ & T6 & $\mathrm{T} 2$ & $\mathrm{~S} 1$ & & \\
\hline Bulgaria & $\mathrm{T} 1$ & T6 & $\mathrm{T} 7$ & T8 & $\mathrm{T} 2$ & & \\
\hline
\end{tabular}

Source: Own elaboration.

In order to determine the desired state, leading to high and very high smartness and competitiveness in the EU, the TOP $10 \mathrm{EU}$ countries were subjected to detailed research on the PSOI RANK. For a clearer visualization and better understanding of the specifics of their development paths, their smartness was analyzed in comparison with the BOTTOM 10 countries.

A further attempt was therefore made to assess the strength and repeatability of the individual PSOI factors in the EU countries that ranked the first 10 (TOP 10) and the last 10 (BOTTOM 10) in the PSOI ranking (Table 6). Factors that presented the three highest and three lowest values in each country were considered.

Table 6. TOP 10 vs. BOTTOM 10 of PSOI RANK.

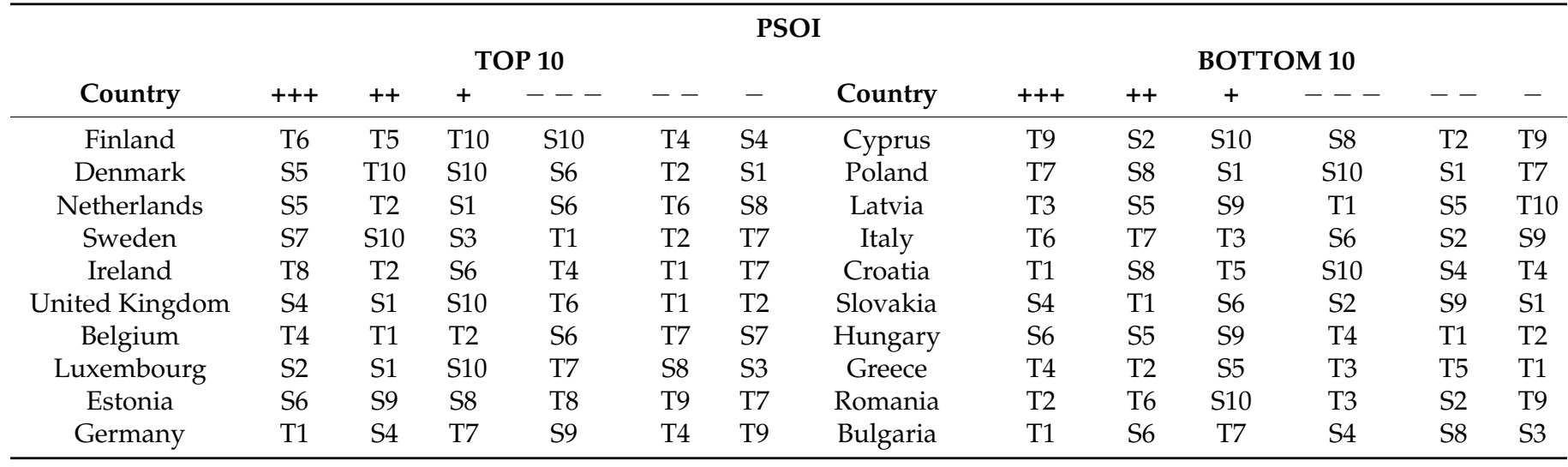

Where +++ is the strongest factor in the country, ++ is the second-strongest factor, + the third-strongest factor and --- is the weakest factor in the country, - - is the second-weakest factor, - is the third-weakest factor. Source: Own elaboration. 
Table 6 shows that the high level of TOP 10 smartness is more often influenced by social factors related to the ability to use advanced technologies in organizations. They prevailed in the strengths of the TOP 10 countries $(S \times 18 / T \times 12)$, while weaknesses in this group were rather related to technological factors $(T \times 19 / S \times 11)$. Most often $($ each $\times 3)$, two social factors were indicated here, namely the individual's broadband access to the Internet (S1), use of cloud services (S10), and one technological factor, namely the enterprise's high and very high level of digital intensity (T10). In the strengths of the BOTTOM 10 countries, social factors were as important as technological ones $(\mathrm{T} \times 15 / \mathrm{S} \times 15)$ but, unfortunately, they were much less developed than in the TOP 10. A similar situation occurred in the weaknesses of this group, where technological factors occurred a similar number of times as social ones $(\mathrm{T} \times 14 / \mathrm{S} \times 16)$. These are quite significant differences. Another is that while the most popular indicators in the TOP 10 were T1, T2, T10, S1, and S10, in the BOTTOM 10, they were T1, T7, S5, and S6. Only T1 connected these groups. This means that weaker countries have shortcomings in the development of crucial success factors T2, T10, S1, and S10. The TOP 10 countries can therefore be considered as benchmarks that have experience in the development of these smart activities.

To gather more information on potential benchmarks in EU smartness and sustainability, the next step of the analysis focuses on the development paths and achievements of the TOP 10 countries. By identifying the countries with the highest values for individual PSOI indicators (T1-T10 and S1-S10), potential benchmarks were isolated in ranges (Table 7). For example, T1-Germany, T2-the Netherlands, T3-Finland, Denmark, the Netherlands, T4-Belgium, etc. seem to be a good benchmark for the successful development of T and S indicators (values in bold in Table 7). A closer look at them show that in technical aspects, the strongest support can be found in Finland and Denmark, while Denmark and Sweden are leading in social aspects.

Table 7. Indicators with the highest values in the TOP 10 group.

\begin{tabular}{|c|c|c|c|c|c|c|c|c|c|c|}
\hline & Finland & Denmark & Netherlands & Sweden & Ireland & $\begin{array}{c}\text { United } \\
\text { Kingdom }\end{array}$ & Belgium & Luxembourg & Estonia & Germany \\
\hline $\mathrm{T} 1$ & 1.07 & 1.25 & 0.54 & -0.52 & -0.69 & -0.69 & 1.78 & 0.37 & -0.16 & 2.48 \\
\hline $\mathrm{T} 2$ & 1.31 & 0.34 & 1.89 & -0.44 & 1.50 & -0.44 & 1.50 & 0.73 & -0.24 & 0.53 \\
\hline T3 & 0.98 & 0.98 & 0.98 & 0.29 & 0.06 & -0.17 & 0.52 & 0.29 & -0.17 & -0.17 \\
\hline $\mathrm{T} 4$ & 0.76 & 1.51 & 1.29 & 0.13 & -0.83 & 0.13 & 1.82 & 0.55 & -1.04 & -0.72 \\
\hline T5 & 2.43 & 1.82 & 1.28 & 1.89 & 1.08 & 0.88 & 0.74 & -0.27 & 0.34 & -0.47 \\
\hline T6 & 3.22 & 1.80 & -0.14 & 0.68 & -0.26 & -0.73 & -0.20 & -0.50 & -0.08 & -0.44 \\
\hline T7 & 1.65 & 2.19 & 1.07 & 0.00 & -0.62 & 0.84 & -0.58 & -0.77 & -0.50 & 1.11 \\
\hline T8 & 2.18 & 1.26 & 1.60 & 1.51 & 1.68 & 0.76 & 0.76 & -0.24 & -0.91 & 0.01 \\
\hline T9 & 1.87 & 0.69 & 0.43 & 1.21 & 1.08 & 0.56 & -0.05 & 0.56 & -0.75 & -0.49 \\
\hline T10 & 2.43 & 2.44 & 1.36 & 1.79 & 0.62 & 0.03 & 0.54 & -0.10 & -0.09 & -0.44 \\
\hline S1 & 1.10 & 0.59 & 1.77 & 1.43 & 0.59 & 1.43 & 0.26 & 1.43 & 0.59 & 0.59 \\
\hline S2 & 1.30 & 1.05 & 0.97 & 1.39 & 1.09 & 1.05 & 0.72 & 1.73 & 0.61 & 0.13 \\
\hline S3 & 1.75 & 1.99 & 1.50 & 2.07 & 0.36 & 0.77 & 0.68 & -0.38 & -0.29 & 0.60 \\
\hline S4 & 0.86 & 1.63 & 1.41 & 1.30 & 0.26 & 1.58 & 0.37 & 0.97 & 0.37 & 1.25 \\
\hline S5 & 1.51 & 2.66 & 2.01 & 0.60 & -0.10 & 0.50 & -0.30 & 0.65 & 0.55 & 0.95 \\
\hline S6 & 2.38 & -0.29 & -1.02 & -0.29 & 1.38 & -0.29 & -0.80 & 0.37 & 2.10 & 1.04 \\
\hline S7 & 2.06 & 1.62 & 0.92 & 2.70 & 0.09 & 0.36 & -0.44 & 0.87 & 1.01 & -0.44 \\
\hline S8 & 1.13 & 0.86 & 0.31 & 0.59 & 1.32 & 0.71 & 0.27 & -0.62 & 1.40 & 0.33 \\
\hline S9 & 1.41 & 1.82 & 1.11 & 1.87 & 0.61 & 0.41 & 0.01 & -0.29 & 1.72 & -0.89 \\
\hline S10 & 0.59 & 2.21 & 1.36 & 2.29 & 1.19 & 1.19 & 0.25 & 1.02 & 0.51 & -0.43 \\
\hline
\end{tabular}

As a result of the multifaceted and multi-stage analyses described above, countries wishing to actively engage in the development of their and the EU's smartness, sustainable development, and competitiveness can be offered several navigation paths to market success based on the development of the smart and sustainable organization. These may be more or less intense, depending on the chosen benchmark and the initial state of the country (i.e., the PSOI ranking).

The first one, based on slow technological development, appears to be the navigation path toward the medium level of smart and sustainable EU 4.0 ("crucial five" smart EU 4.0, 
Table 5). This pathway should aim to achieve the highest possible levels for the following indicators:

1. T1-Business processes automatically linked to suppliers and/or customers,

2. T3-Broadband access to the Internet,

3. T4-Integration of internal processes in enterprises,

4. T9-ICT specialists in enterprises, and

5. T10-High and very high level of the digital intensity index in enterprises.

The second, more dynamic, and at the same time more diversified (because it is based on the uniform development of social and technical factors) path may turn out to be a path based on the observation of the smart activity of the TOP 10 countries (Table 6). This path requires the following indicators to be increased:

1. T1-business processes automatically linked to suppliers and/or customers,

2. T2-Big Data analysis in enterprises,

3. T10-high and very high level of the digital intensity index in enterprises,

4. S1-individuals with broadband access to the Internet, and

5. S10-individual use of cloud services.

The third one, which is ambitious and requires costly, dynamic technological development, but is consequently highly effective, will be to observe the leader of smart and sustainable EU IR 4.0 - the country in first place in the PSOI rank-currently Finland (Table

4). In this case, the following indicators should be strengthened:

1. T3-broadband access to the Internet,

2. T5-enterprises using cloud computing services,

3. T6 - enterprises sending electronic invoices suitable for automatic processing,

4. T8-ICT risk assessments in enterprises, and

5. T9-ICT specialists in enterprises.

By generating an environment that is conducive and supportive to the development of the key parameters for smart organization development (actions/programs/investments expanding their activities in the mentioned $\mathrm{T}$ and $\mathrm{S}$ factors), the authorities of particular countries may have a chance to more consciously and effectively stimulate not only the smartness and competitiveness of these organizations, but also of the whole economy. The stimulation of the development of smartness at the micro level, in the era of globalization, widely understood networks (including social, environmental, technical), borderless organization, and modern technologies of the Industry 4.0 era have a significant and relatively fast reflection not only at the regional (mezzo), but also at the macro level (international, European, and even global).

It seems that the above analyses and the resulting observations make it possible to positively verify hypotheses $\mathrm{H} 1-\mathrm{H} 4$ posed at the beginning of the study. They also provide answers to research questions Q3-Q5.

\subsection{Power of Smart Organizations Index (PSOI)—Fragmentary Analysis}

Considering that smart organizations contribute to the 17 Sustainable Development Goals, it was decided to check whether their existence in a given country translates into specific actions in this aspect. The 7th goal of the 2030 Agenda for Sustainable Development (Affordable and Clean Energy) is one example. An R Pearson test was conducted to detect the correlation between PSOI and share of renewable energy in gross final energy consumption in EU countries (Eurostat data).

Looking into that source of confirmation of the impact of smart organization on the competitiveness of the EU as well as the pace and level of implementation of the EU's sustainable development, a statistically significant relationship was found between the PSOI indicator proposed in the study and the energy efficiency and the ability to acquire and use renewable energy, which have been strategic for the entire sustainable world in recent years. On a macro scale, the share of renewable energy in gross final energy consumption in individual EU countries is as shown in Table 8. 
Table 8. Share of renewable energy in gross final energy consumption.

\begin{tabular}{|c|c|c|c|c|}
\hline \multicolumn{2}{|c|}{ SRE } & \multicolumn{2}{|c|}{ PSOI } & \multirow[t]{2}{*}{ R Pearson } \\
\hline Sweden & 56.39 & Finland & 31.98 & \\
\hline Finland & 43.08 & Denmark & 28.41 & \multirow{27}{*}{0.958413759} \\
\hline Latvia & 40.97 & Netherlands & 20.65 & \\
\hline Denmark & 37.2 & Sweden & 20.5 & \\
\hline Austria & 33.62 & Ireland & 10.4 & \\
\hline Estonia & 31.88 & United & 8.86 & \\
\hline Portugal & 30.61 & Belgium & 7.86 & \\
\hline Croatia & 28.46 & Luxembourg & 6.38 & \\
\hline Lithuania & 25.46 & Estonia & 4.93 & \\
\hline Romania & 24.29 & Germany & 4.55 & \\
\hline Slovenia & 21.66 & France & 3.54 & \\
\hline Bulgaria & 20.59 & Austria & 2.25 & \\
\hline Greece & 19.67 & Spain & 1.94 & \\
\hline Spain & 18.35 & Slovenia & 1.51 & \\
\hline Italy & 18.16 & Malta & 0.65 & \\
\hline Germany & 17.35 & Lithuania & -1.73 & \\
\hline France & 17.21 & Czech & -5.19 & \\
\hline Slovakia & 16.89 & Portugal & -5.51 & \\
\hline Czech Republic & 16.24 & Cyprus & -8.04 & \\
\hline Cyprus & 13.8 & Poland & -8.15 & \\
\hline Hungary & 12.61 & Latvia & -9.63 & \\
\hline United Kingdom & 12.33 & Italy & -10.16 & \\
\hline Poland & 12.16 & Croatia & -11.60 & \\
\hline Ireland & 11.98 & Slovakia & -12.07 & \\
\hline Belgium & 9.92 & Hungary & -14.42 & \\
\hline Netherlands & 8.76 & Greece & -17.97 & \\
\hline Malta & 8.48 & Romania & -25.80 & \\
\hline Luxembourg & 7.04 & Bulgaria & -27.64 & \\
\hline
\end{tabular}

Source: Eurostat database, 2020.

The above data show that there is a high level of correlation between the ability of individual EU countries to develop the potential of smart organizations and their "smartness of country", and the achievements of these countries (and the EU as a whole) in the use of renewable energy. This means that countries where organizations have, to a large extent, reached the level of smart development, are not only proficient in the use of new technologies and the accompanying knowledge but are also able and willing to consciously combine economic, technical, social, and environmental aspects. In this way, they realize significant benefits for themselves and their environment, not only economic but also social such as those resulting from the implementation of sustainable development objectives in the field of care for the environment (the 7th Sustainable Development Goal). Therefore, it can be expected that their support will not only be visible, but also very important for the implementation of the other 16 EU sustainability goals for the coming years [63].

\section{Discussion}

The analyses carried out showed that research on the essence and role of smart and sustainable organizations in the modern economy (IR 4.0 era) is an important and topical issue $[30,57]$. Unfortunately, it is still neglected. While attempts have been made to define them [47], their specificity, effectiveness, or development possibilities are still rarely examined [19]. Moreover, their individual cases are more often described than the activity of a larger number of such entities and their impact on the modern economy has been reported. More comprehensive smartness analyses tend to focus on cities and regions [14-18] rather than individual countries or larger systems such as the EU. EU countries have been analyzed in various summary documents either from the perspective of competitiveness or sustainable development [124,126,127], but there have been few attempts to take an integrated approach to these two aspects together. The few studies 
that have analyzed the above or similar issues, however, confirm in different ways the phenomena identified in this paper $[7,10]$. It can be seen that the results of the development of smart and sustainable organizations have a positive impact on the contemporary economy $[7,10,126]$, industry $[45,57]$, and society $[127,128]$, and thus on their competitiveness and achieving objectives of sustainable development according to the 2030 Agenda for Sustainable Development.

The tool we proposed (PSOI) in this paper allowed us to integrate the above-mentioned areas of analysis into a single construct, based on the observation of the smart organizations' determinants of the development and their impact on the smartness and sustainability of their countries of operation. Our research also contributes to the discussion on the significance of the features of smartness and their value as drivers of competitiveness and sustainable development both at the micro (organizations) and macro (countries) levels. It seeks to offer an integrated approach to this issue. It therefore complements, and to some extent consolidates, previous research on corporate sustainability [7,10,19,127-130] and ICT's impact on social, economic, and environmental development.

It is worth noting that due to its specificity, our research has a pioneering character. By identifying factors of smart organizations, it allows not only for the identification and mapping of countries in terms of competitiveness, smartness, and sustainability, but also to navigate them toward smarter and more sustainable development. These issues have not yet been analyzed and described in such an integrated way in the context of competitiveness and sustainable development of the EU as a whole as well as individual member states. Maps presented in the literature have so far only been created for different, more specific aspects such as Roadmap for the Sustainable and Smart Mobility Strategy, Roadmap for an EU Smart Sector Integration Strategy, Heat Roadmap Europe, European Roadmap Toward an Integrated Urban Mobility System, etc.

In the authors' opinion, for all countries for which data on individual PSOI factors can be collected, processes of navigation and mapping toward more competitive, smarter, and more sustainable development can be implemented. Future research directions of the power of Smart and Sustainable Organizations may comprise an analysis of their usage in the Smart and Sustainable development of different sectors, branches, or industries. In our opinion, the proposed tool (PSOI) could also be the basis for developing a platform, software, or application to systematically monitor how competitiveness and sustainability objectives are being achieved in individual countries.

\section{Conclusions}

In general terms, the competitiveness and sustainability of a country is understood as the capacity for long-term and effective growth, and it is usually juxtaposed in the literature with institutional conditions and the role of the human factor in shaping it. This article has allowed the competitiveness and sustainability of EU countries to be viewed from a different perspective: through smart and sustainable organizations, which distribute their achievements and thus set and support the direction of development for their whole environment.

In the opinion of the authors, there is a strong link between the level of development on a micro level (the level of an organization) and the level of development on a macro scale (the level of individual countries' economies). Therefore, it is necessary to systematically monitor the effectiveness of their development and to consciously create conditions supporting them in this respect. Dedicated tools in the field of economics, management, and ICT and mechanisms should be used (such as the efficient collection and systematic analysis of relevant statistical data, publicly available surveys of social opinion, and consultations with businesses, partnerships, and intersectoral cooperation strategies, clear rules for supporting key activities for competitiveness and sustainable development goals of a given country). The effectiveness and sophistication of the work in preparing, implementing, and operating these solutions varies from country to country. In 
general, there are perceived problems in systematically navigating the development and exploitation of opportunities in today's smart organizations in a targeted manner.

The tool proposed in the study may be a solution in support of solving such issues. It can be one of the elements of monitoring both the competitiveness and sustainable development of modern economies based on the "power" of smart organizations. By tracking, in a statistically structured way, the scale and effectiveness of smart organizations (characterized by the features included in the PSOI index) both those operating in a given country and others, public authorities can compare the effectiveness of international solutions undertaken to support them. From the effectiveness of the observed experiences, conclusions, inspirations, and recommendations can be drawn for further decisions in this field. For EU countries, it seems particularly useful to use the system of navigation paths proposed in the study. These are different approaches to exploiting the potential of smart organizations, depending on national circumstances and local policies. The use of one of the paths recommended for a given research period (paths should be updated after the analysis of statistical data collected in the following year) allows for a more conscious selection of benchmark countries that may inspire specific steps in terms of, for example, Area I of the scale of investment, type of tax solutions, size of subsidies, reliefs, or whole strategies for the development of specific industries or otherwise defined areas. This is signaled by the factors assigned to each path described by specific variables included in the PSOI index proposed in the study (see more in Tables 5-7).

The proposed solution seems to be justified, as the results of the studies carried out have shown that there is a Europe of different speeds in this respect, with different levels of use of the factors influencing the level of smartness, and thus different levels of competitiveness and sustainability (see Table 4).

Choosing the right path seems all the more important given that the starting point (i.e., the level of development of smart organizations and their operating environment so far) varies from country to country. Data collected in 2020 during the testing of the tool for $28 \mathrm{EU}$ countries indicate that initially, strengthening social aspects should become a priority. This means that social smartness is a basis for smart and sustainable EU 4.0. However, the main long-term objective should be a high balance of technological and social indicators. Consequently, the organization's knowledge of the factors to develop in the first place and the factors that can be achieved at a high level in the long run is important. A conscious navigation in the direction of the designated pattern/benchmark becomes extremely important on the way to smartness and sustainable development. It should be borne in mind that there may be different benchmarks for different countries, and thus different pathways for reaching the objective. A model could be, for example, the mean uniform level of smart and sustainable EU 4.0, the level of TOP 10 countries, or the level of EU leader in this field (currently Finland). It is also possible to search for an appropriate benchmark among the countries with the highest scores on a given indicator, depending on the needs of the benchmarker, and to follow them in achieving a similar level of smartness and sustainability. In addition, in the absence of a long-term strategy for building competitiveness and sustainable development based on smart organizations, short-term plans can be adopted to build on the direct competitors that are closest to the top of the PSOI ranking.

Referring to the 2030 Sustainable Development Agenda, research on the example of Goal 7 (Affordable and Clean energy) confirms that smart organizations can be expected to support most of the Sustainable Development Goals (SDGs), affecting not only the future of Europe, but also of the whole world.

Thanks to the implementation of studies of EU countries with the proposed tool (PSOI), a list of factors generating the smartness and sustainability of organizations and countries was created as well as a database, a smart EU IR 4.0 map, and a list of recommended development paths for the smartness and sustainable development of countries. They allow individual countries to identify their position and their benchmarks in terms of smartness and sustainability based on smart and sustainable organizations. They also 
make it easier to choose the right path of development and navigate toward smart and sustainable EU 4.0. The integration of micro and macro perspectives proposed in the study also offers many other benefits. By systematically updating the data in the PSOI database following the publication of subsequent annual data in Eurostat and European or global competitiveness and sustainable development rankings, there also emerges the possibility of systematic, long-term monitoring of progress in the development level of smart and sustainable EU 4.0 and the competitiveness and sustainable development of EU countries based on the knowledge of smart and sustainable organizations. Therefore, it seems that the objectives set for this study have been achieved, the hypotheses were positively verified, and the research questions have received concrete answers.

The results of this research are the product of a multi-stage research process. However, it is important to mention the existing research constraints that have emerged during the course of the studies. These are mainly due to a lack of conceptual order in the literature. The concepts of IR 4.0, smartness, sustainability, and competitiveness are very broad, undefined, or defined in numerous different ways. The lack of unambiguous definitions makes them difficult to describe and assess with certainty. Another limitation was the poor availability of indicators ideally suited to the characteristics of smart organizations or comparable at the same time. As a result, their selection had to be modified on purpose. Such comparative surveys therefore require appropriate building of official statistics by the relevant institutions at the EU level. It should also be stressed that the PSOI ranking does not ideally coincide with the competitiveness and sustainability rankings, with unintended deviations in the positions of individual countries. This was due to the fact that the competitiveness and sustainability rankings were broader studies, which consisted of a larger spectrum of indicators. The large differences in performance between countries in the PSOI ranking were due to large discrepancies in the development of the digital economy and society. The worst situation is seen in the last countries to join the EU.

Author Contributions: Conceptualization, A.A. (50\%) and D.S.-F. (50\%); Methodology, A.A. (50\%) and D.S.-F. (50\%); Investigation, A.A. (50\%) and D.S.-F. (50\%); Resources, A.A. (50\%) and D.S.-F. (50\%); Writing-original draft preparation, A.A. (50\%) and D.S.-F. (50\%); Writing-review and editing, A.A. (50\%) and D.S.-F. (50\%); Visualization, A.A. (50\%) and D.S.-F. (50\%); Supervision, funding acquisition, A.A. (50\%) and D.S.-F. (50\%). All authors have read and agreed to the published version of the manuscript.

Funding: This research received no external funding. Publication financed by resources from two Universities: $\frac{1}{2}$ the Faculty of Management and Production Engineering, Department of Management, Lodz University of Technology, Poland; $\frac{1}{2}$ the Faculty of Management, University of Lodz, Poland.

Data Availability Statement: Data received from Eurostat Database https:/ / ec.europa.eu/eurostat/ data/database.

Conflicts of Interest: The authors declare no conflict of interest.

\section{References}

1. Deloitte. Deloitte Insights: The Fourth Industrial Revolution is Here-Are You Ready? Deloitte: London, UK, 2018.

2. Fonseca, L.M. Industry 4.0 and the digital society: Concepts, dimensions and envisioned benefits. Proc. Int. Conf. Bus. Excell. 2018, 12, 386-397. [CrossRef]

3. Porter, M.E.; Heppelmann, J.E. How smart, connected products are transforming competition. Harv. Bus. Rev. 2014, 92, 64-88.

4. Ślusarczyk, B. Industry 4.0-are we ready? Polish J. Manag. Stud. 2018, 17, 232-248. [CrossRef]

5. Hansen, U.E.; Nygaard, I.; Romijn, H.; Wieczorek, A.; Kamp, L.M.; Klerkx, L. Sustainability transitions in developing countries: Stocktaking, new contributions and a research agenda. Env. Sci. Policy 2018, 84, 198-203. [CrossRef]

6. Verhees, B.; Verbong, G.P.J. Users, Consumers, Citizens: A systematic review of their roles in sustainability transitions. Eindhoven 2015, 201504, 1-39.

7. Patela, Y.; Doshi, N. Social implications of smart cities. Procedia Comput. Sci. 2019, 155, 692-697. [CrossRef]

8. Oliveira, P.; von Hippel, E. Users as service innovators: The case of banking services. Res. Policy 2011, 40, 806-818. [CrossRef]

9. Harting, R.C.; Reichstein, C.; Hartle, N.; Stiefl, J. Potentials of digitisation in the tourism industry-empirical results from German experts. In International Conference on Business Information Systems; Springer: Cham, Switzerland, 2017; pp. 165-178. 
10. Miller, M. The Internet of Things: How Smart TVs, Smart Cars, Smart Homes and Smart Cities Are Changing the World; Pearson Education Inc.: New York, NY, USA, 2015.

11. Kang, H.S.; Lee, J.Y.; Choi, S.; Kim, H.; Park, J.H.; Son, J.Y.; Kim, B.H.; Noh, S.D. Smart manufacturing: Past research, present findings, and future directions. Int. J. Precis. Eng. Manuf. Green Technol. 2016, 3, 111-128. [CrossRef]

12. Magal, S.; Slivka, M. Virtual reality in tourism. In Conference Proceedings, Proceedings of the 7th Advances in Hospitality $\mathcal{E}$ Tourism Marketing $\mathcal{E}$ Management (AHTMM) Conference, Famagusta, Cyprus, 10-15 July 2017; Eastern Mediterranean University and Washington State University: Famagusta, Cyprus, 2017; pp. 59-72.

13. Gutierrez, V.; Galache, J.A.; Santana, J.R.; Sotres, P.; Sanchez, L.; Munoz, L. The Smart City Innovation Ecosystem: A Practical Approch. IEEE Comsoc. Mmtc. E-Lett. 2014, 9, 35-39.

14. Caragliu, A.; Del Bo, C.; Nijkamp, P. Smart Cities in Europe. J. Urban Technol. 2011, 18, 65-82. [CrossRef]

15. Komninos, N. Intelligent Cities and Globalisation of Innovation Networks; Routledge: London, UK; New York, NY, USA, 2008.

16. Lombardi, P.; Giordano, S.; Farouh, H.; Yousef, W. Modelling the smart city performance. Innov. Eur. J. Soc. Sci. Res. 2012, 25, 137-149. [CrossRef]

17. Sikora-Fernandez, D. Smarter cities in post-socialist country: Example of Poland. Cities 2018, 78, 52-59. [CrossRef]

18. Sikora-Fernandez, D.; Stawasz, D. The concept of smart city in the theory and practice of urban development management. Rom. J. Reg. Sci. 2016, 10, 81-99.

19. Santana, A.A.; Gil, S.M. Cooperation and competition among regions: The umbrella brand as a tool for tourism competitiveness. In Geopolitics and Strategic Management in the Global Economy; IGI Global: Hershey, PA, USA, 2018; pp. 315-336.

20. McCann, P.; Ortega-Argiles, R. Smart specialisation, entrepreneurship and SMEs: Issuees and challanges for a result-oriented EU regional policy. Small Bus. Econ. 2016, 46, 537-552.

21. Adamik, A. SMEs on the way to SMART World of Industry 4.0. In Proceedings of the 25th Eurasia Business and Economics Society Conference, Serie: Eurasian Studies in Business and Economics; Bilgin, M.H., Danis, H., Eds.; Springer: Cham, Switzerland, 2020; Volume 2, pp. 3-43.

22. World Economic Forum, 2012, The Europe 2020 Competitiveness Report: Building a More Competitive Europe. p. 2. Available online: www.weforum.org/Europe2020 (accessed on 15 July 2020).

23. Meyer-Stamer, J. Systematic Competitiveness and Local Economic Development Discussion Paper; Mesopartner: Duisberg, Germany, 2008.

24. Schwab, K.; Porter, M.E. The Global Competitiveness Report 2007-2008; World Economic Forum: Geneva, Switzerland, 2007.

25. Annoni, P.; Dijkstra, L. The EU Regional Competitiveness Index; Publications Office of the European Union: Luxembourg, 2019 ; p. 3.

26. Adamik, A.; Nowicki, M. Preparedness of Companies for Digital Transformation and Creating a Competitive Advantage in the Age of Industry 4.0. In Proceedings of the International Conference on Business Excellence; Sciendo: Warszawa, Poland, 2018; pp. 10-24.

27. Hermann, M.; Pentek, T.; Otto, B. Design Principles for Industries 4.0 Scenarios: A Literature Review. Working Paper No. 01/2015. Available online: http:/ / www.thiagobranquinho.com/wp-content/uploads/2016/11/Design-Principles-for-Industrie4 - 0 -Scenarios.pdf (accessed on 15 July 2020).

28. Maynard, A.D. Navigating the fourth industrial revolution. Nat. Nanotechnol. 2015, 10, 1005-1006.

29. Gaub, H. Customisation of mass-produced parts by combining injection molding and additive manufacturing with Industry 4.0 technologies. Reinf. Plast. 2016, 60, 401-404. [CrossRef]

30. Janik, A.; Ryszko, A. Mapping the field of Industry 4.0 based on bibliometric analysis. In Proceedings of the 32nd IBIMA Conference, Seville, Spain, 15-16 November 2018.

31. Adamik, A.; Nowicki, M.; Szymańska, K. Openness to co-creation as a method of reducing the complexity of the environment and dynamisation of the competitive advantage of companies. Manag. Mark. Chall. Knowl. Soc. 2018, 13, 880-896.

32. Adamik, A. Creating of competitive advantage in the age of INDUSTRY 4.0. Manag. Issues Organ. Manag. Issues Age Ind. 4.0 2019, 17, 13-31. [CrossRef]

33. Ajdovec, P.; Kovacic, B.R.; Vidmar, M. Corporate strategy and Industry 4.0: Bibliometric analysis on factors of modernisation. Dyn. Relatsh. Manag. J. 2017, 6, 47-59. [CrossRef]

34. Basl, J. Pilot study of readiness of czech companies to implement the principles of Industry 4.0. Manag. Prod. Eng. Rev. 2017, 8, 3-8. [CrossRef]

35. Bender, M.; Willmott, P. Digital Reinvention; McKinsey \& Company: Chicago, IL, USA, 2017.

36. Kamblea, S.S.; Gunasekaranb, A.; Rohit Sharmac, R. Analysis of the driving and dependence power of barriers to adopt industry 4.0 in Indian manufacturing industry. Comput. Ind. 2018, 101, 107-119. [CrossRef]

37. Pfohl, H.C.; Yahsi, B.; Kurnaz, T. The impact of Industry 4.0 on the supply chain. HICL 2015, 20, 31-58.

38. Smart Future Initiative. 2016. Available online: http:/ / smart-future.net/1.html (accessed on 15 July 2020).

39. Lee, S.M.; Trimi, S. Innovation for creating a smart future. J. Innov. Knowl. 2018, 3, 1-8. [CrossRef]

40. Streitz, N. Citizen-centered design for human and sociable hybrid cities. In Hybrid City 2015-Data to the People, Proceedings of the 3rd International Biannual Conference, Leuven, Belgium, 15-17 September 2010; Theona, I., Charitos, D., Eds.; Association for Computing Machinery: New York, NY, USA, 2015; pp. 17-20.

41. Kramer, M.R.; Pfitzer, M.W. The ecosystem of shared value. Harv. Bus. Rev. 2016, 94, 81-89.

42. Canton, J. Future Smart: Managing the Gam-Changing Trends that will Transform Your World; Da Capo Press: Boston, MA, USA, 2015. 
43. Iapichino, A.; De Rosa, A.; Liberace, P. Smart Organisations, New Skills, and Smart Working to Manage Companies' Digital Transformation. In Digitized Labor; Pupillo, L., Noam, E., Waverman, L., Eds.; Palgrave Macmillan: Cham, Switzerland, 2018. [CrossRef]

44. Calin, I.E.; Pargaru, I.; Neascu, M. The Role of Smart Organisation in Socio-Economic Environment. Valahian J. Econ. Stud. 2015, 6, 41-47.

45. Liu, H.; Ning, H.; Mu, Q.; Zheng, Y.; Zeng, J.; Yang, L.T.; Huang, R.; Ma, J. A Review of smart world. Future Gener. Comput. Syst. 2019, 96, 678-691. [CrossRef]

46. Ma, J.; Yang, L.T.; Apduhan, B.O.; Huang, R.; Barolli, L.; Takizawa, M. Towards a smart world and ubiquitous intelligence: A walkthrough from smart things to smart hyperspaces and UbicKids. Int. J. Pervasive Comput. Commun. 2015, 1, 53-68. [CrossRef]

47. Al-Kasasbeh, M.M.; Al-Kasasbeh, S.A.M.; AL-Faouri, A.H. Smart organisation characteristics and its impact on social and environmental performance: An empirical study on Jordan phosphate mines company. Int. J. Bus. Manag. 2016, 11, 106. [CrossRef]

48. Kiel, D.; Muller, J.M.; Arnold, C.; Voigt, K.I. Sustainable industrial value creation: Benefits and challanges of Industry 4.0. Int. J. Innov. Manag. 2017, 21. [CrossRef]

49. Sydänmaanlakka, P. An Intelligent Organisation. Integrating Performance, Competence and Knowledge Management; Capstone: London, UK, 2002.

50. Glatterfelder, J.B. Backbone of Complex Networks of Corporations: The Flow of Control. In Decoding Complexity. Springer Theses (Recognizing Outstanding Ph. D. Research); Springer: Berlin/Heidelberg, Germany, 2013.

51. Bratianu, C.; Vasilache, S.; Jianu, I. In Search of Intelligent Organisations. Manag. Mark. 2006, 1, 71-82.

52. Filos, E. Smart organisations in the digital age. In Integration of ICT in Smart Organisations; Mezgar, I., Ed.; Idea Group Publishing: Hershey, PA, USA, 2006; pp. 1-38.

53. Adamczewski, P. ICT solutions in intelligent organisations as challenges in a knowledge economy. Management 2016, 20, 199-200. [CrossRef]

54. Putnik, G.; Cunha, M.M. (Eds.) Virtual Enterprise Integration: Technological and Organisational Perspectives; IDEA Group Publishing: Hershey, PA, USA, 2005.

55. Carley, K.M. Smart Agents and Organisations of the Future; Carnegie Mellon University: Pittsburgh, PA, USA, 2001.

56. Valenduc, G.; Vendramin, P. Work in the Digital Economy: Sorting the Old from the New; ETUI: Brussels, Belgium, 2001.

57. Mohamed, M. Challenges and benefits of Industry 4.0: An overview. Int. J. Supply Oper. Manag. 2018, 5, $256-265$.

58. Wales, T. Organisational sustainability: What is it, and why does it matter? Rev. Enterp. Manag. Stud. 2013, 1, 38-49.

59. Report of the World Commission on Environment and Development: Our Common Future. Available online: https:// sustainabledevelopment.un.org/content/documents/5987our-common-future.pdf (accessed on 17 January 2021).

60. Saunila, M.; Nasiri, M.; Ukko, J.; Rentala, T. Technologies and corporate sustainability: The mediation effect of corporate sustainability strategy. Comput. Ind. 2018, 108, 178-185. [CrossRef]

61. Chen, D.; Heyer, S.; Ibbotson, S.; Salonitis, K.; Steingrímsson, J.G.; Thiede, S. Direct digital manufacturing: Definition, evolution, and sustainability implications. J. Clean. Prod. 2015, 107, 615-625. [CrossRef]

62. Bechtsis, D.; Tsolakis, N.; Vlachos, D.; Srai, J.S. Intelligent Autonomous Vehicles in digital supply chains: A framework for integrating innovations towards sustainable value networks. J. Clean. Prod. 2018, 181, 60-71. [CrossRef]

63. 2030 Agenda for Sustainable Development. Available online: https://sdgs.un.org/2030agenda (accessed on 19 December 2020).

64. Bruni, A.; Pinch, T.; Schubert, C. Technologically Dense Environments: What For? What Next? Tecnoscienza. Ital. J. Sci. Technol. Stud. 2013, 4, 51-72.

65. Orlikowski, W.J.; Scott, S.V. Sociomateriality: Challenging the Separation of Technology, Work and Organisation. Acad. Manag. Ann. 2008, 2, 433-474. [CrossRef]

66. Mindas, M.; Bednar, S. Mass Customisation in the context of Industry 4.0: Implications of variety-inducted complexity. In Advanced Industrial Engineering Industry 4.0; Plinta, D., Ed.; Fundacja Centrum Nowych Technologii: Bielsko-Biała, Poland, 2016; pp. 21-39.

67. Graham, D.; Manikas, I.; Folinas, D. E-logistics and E-Supply Chain management. Applications for Evolving Business; IGI Global: Hershey, PA, USA, 2013.

68. Mehdipour, F.; Noori, H.; Javadi, B. Energy-Efficient Big Data Analytics in Datacenters. Adv. Comput. 2016, 100, 59-101. [CrossRef]

69. Perera, C.; Ranjan, R.; Wang, L.; Khan, S.; Zomaya, A. Privacy of BigData in the Internet of Things Era. IEEE IT Prof. Mag. PrePrint Internet Anything 2014. [CrossRef]

70. Li, D.; Tang, H.; Wang, S.Y.; Liu, C.L. A big data enabled load-balancing control for smart manufacturing of Industry 4.0. Cluster Comput. J. Netw. Softw. Tools Appl. 2017, 20, 1855-1864. [CrossRef]

71. Verdugo Cedeno, J. Developing smart services by Internet of Things in Manufacturing Business. GMIT Thesis, Lappeenranta University of Technology, Lappeenranta, Finland, 2016.

72. Arnold, C.; Kiel, D.; Voigt, K.-I. How the industrial internet of things changes business models in different manufacturing industries. Int. J. Innov. Manag. 2016, 20. [CrossRef]

73. Ehret, M.; Wirtz, J. Unlocking value from machines: Business models and the industrial internet of things. J. Mark. Manag. 2017, 33, 111-130. [CrossRef] 
74. Tesch, J.F.; Brillinger, A.S.; Bilgeri, D. Internet of things business model innovation and the stage-gate process: An exploratory analysis. Int. J. Innov. Manag. 2017, 21, 1-19. [CrossRef]

75. Barry, D.K. Web Services. Service-Oriented Architectures and Cloud Computing; Morgan Kaufmann Publishers: New York, NY, USA, 2017.

76. Lee, E. Cyber Physical Systems: Design Challenges. In Proceedings of the 11th IEEE Symposium on Object Oriented Real-Time Distribuated Computing (ISORC), Orlando, FL, USA, 5-7 May 2008; pp. 363-369.

77. Baxter, G.; Sommerville, I. Socio-technical systems: From design methods to systems engineering. Interact. Comput. 2011, 23, 4-17. [CrossRef]

78. Lee, J.; Bagheri, B.; Kao, H.-A. A cyber-physical systems architecture for industry 4.0-based manufacturing systems. Manufactring Lett. 2015, 3, 18-23. [CrossRef]

79. Wan, J. Advances in cyber-physical systems research. KSII Trans. Internet Inf. Syst. 2011, 5, 1891-1908. [CrossRef]

80. Grance, T.; Mell, P. The NIST Definition of Cloud Computing. National Institute of Standars and Technology U.S. Department of Commerce. Special Publication. Available online: http:/ /nvlpubs.nist.gov/nistpubs/Legacy/SP/nintspecialpublication8000-145. pdf (accessed on 13 January 2020).

81. Zissis, D.; Lekkas, D. Addressing cloud computing security issues. Future Gener. Comput. Syst. 2012, 28, 583-592. [CrossRef]

82. Hossain, M.S.; Muhammad, G. Cloud-assisted Industrial Internet of Things (IIoT) —Enabled framework for health monitoring. Comput. Netw. 2016, 101, 192-202. [CrossRef]

83. Lee, J.; Kao, H.-A.; Yang, S. Service innovation and smart analytics for Industry 4.0 and big data environment. Procedia CIRP 2014, 16, 3-8. [CrossRef]

84. MIT Editorial.: 10 Breakthrough Technologies 2018, MIT Technology Review March/April2018. Available online: https://www. technologyreview.com/10-breakthrough-technologies/2018/ (accessed on 19 December 2020).

85. Höller, J.; Tsiatsis, G. From Machine-to-Machine to the Internet of Things: Introduction to a New Age of Intelligence; Elsevier: Amsterdam, The Netherlands, 2014.

86. Radziwon, A.; Bilberg, A.; Bogers, M.; Madsen, E. Evaluation the SMART Factory: Exploring Adaptive and Flexible Manufacturing Solutions. Procedia Eng. 2014, 69, 1184-1190. [CrossRef]

87. Deloitte.: Industry 4.0. Challenges and Solutions for the Digital Transformation and Use of Exponential Technologies 2014. Available online: https://www2.deloitte.com/content/dam/Deloitte/ch/Documents/manufacturing/ch-en-manufacturingindustry-4-0-24102014.pdf (accessed on 15 July 2020).

88. Wang, S.; Wan, J.; Li, D.; Zhang, C. Implementing smart factory of industrie 4.0: An outlook. Int. J. Distrib. Sens. Netw. 2016, 12, 1-10. [CrossRef]

89. Dubois, É.; Heymans, P.; Mayer, N.; Matulevičius, R. A systematic approach to define the domain of information system security risk management. In Intentional Perspectives on Information Systems Engineering; Nurcan, S., Salinesi, C., Souveyet, C., Ralyté, J., Eds.; Springer: Berlin/Heidelberg, Germany, 2010.

90. Jiunn-Woei, L. Understanding cloud-based BYOD information security protection behaviour in smart business: In perspective of perceived value. Enterp. Inf. Syst. 2020. [CrossRef]

91. Suszyński, C. Revolutionary Context of the Evolution of a Business Enterprise, A. In Contemporary Challenges in Cooperation and Coopetition in the Age of Industry 4.0; Zakrzewska-Bielawska, A., Staniec, I., Eds.; Springer Proceedings in Business and Economics, Springer Nature Switzerland AG: Cham, Switzerland, 2020; pp. 345-359. [CrossRef]

92. Chas, A. Artificial Intelligence Technologies and Their Categories. Available online: https://www.auraportal.com/artificialintelligence-technologies-and-their-categories / (accessed on 19 August 2020).

93. Geissbauer, R.; Vedso, J.; Schrauf, S. Industry 4.0: Building the Digital Enterprise: 2016 Global Industry 4.0 Survey; PwC: London, UK, 2016.

94. Plinta, D. New Information Technologies in production enterprises. In Advanced Industrial Engineering Industry 4.0; Plinta, D., Ed.; Fundacja Centrum Nowych Technologii: Bielsko-Biała, Poland, 2016; pp. 7-20.

95. Oesterreich, T.D.; Teuteberg, F. Understanding the implications of digitisation and automation in the context of Industry 4.0: A triangulation approach and elements of a research agenda for the construction industry. Comput. Ind. 2016, 83, 121-139. [CrossRef]

96. Bauer, W.; Schlund, S.; Hornung, T.; Schuler, S. Digitalisation of industrial value chains-A review and evaluation of existing use cases of Industry 40 in Germany. LogForum 2018, 14, 331-340. [CrossRef]

97. Eurofound and the International Labour Office. Working Anytime, Anywhere: The Effects on the World of Work, Publications Office of the European Union; Luxemburg and the International Labour Office: Geneva, Switzerland, 2017; Available online: https: / www. eurofound.europa.eu/publications/report/2017/working-anytime-anywhere-the-effects-on-the-world-of-work (accessed on 15 July 2020).

98. Bloom, N.; Liang, J.; Roberts, J.; Ying, Z.J. Does Working from Home Work? Evidence from a Chinese Experiment (Working Paper No. 18871). Q. J. Econ. 2015, 130, 165-218. [CrossRef]

99. Soroui, S.T. Understanding the drivers and implications of remote work fromthe local perspective: An exploratory study into the dis/reembedding dynamics. Technol. Soc. 2021, 64. [CrossRef]

100. Presbitero, A. Foreign language skill, anxiety, cultural intelligence and individual task performance in global virtual teams: A cognitive perspective. J. Int. Manag. 2020, 26. [CrossRef] 
101. Polman, P.; Bhattacharya, C. Engaging employees to create a sustainable business. Stanf. Soc. Innov. Rev. 2016, 14, 34-39.

102. Mishra, A.; Akman, I. Gender, age and income differences in internet usage among employees in organisations. Comput. Hum. Behavior. 2010, 26, 482-490. [CrossRef]

103. Castellacci, F.; Viñas-Bardolet, C. Internet use and job satisfaction. Comput. Hum. Behav. 2019, 90, 141-152. [CrossRef]

104. Savage, D.; Fai Chan, H.; Moy, N.; Schaffner, M.; Torgler, B. Personality and individual characteristics as indicators of lifetime climbing success among Everest mountaineers. Personal. Individ. Differ. 2020, 162. [CrossRef]

105. Zhang, W.; Xu, F.; Sun, B. Are open individuals more creative? The interaction effects of leadership factors on creativity. Personal. Individ. Differ. 2020, 163. [CrossRef]

106. Siemsen, E.; Aleda, V.; Roth, A.V.; Balasubramanian, S. How motivation, opportunity, and ability drive knowledge sharing: The constraining-factor model. J. Oper. Manag. 2008, 26, 426-445. [CrossRef]

107. Zaisheng, Z.; Fang, S.; Zongbin, S. Promoting knowledge sharing in the workplace: Punishment v. reward. Chaos Solitons Fractals 2020, 131. [CrossRef]

108. Dong, Y.; Bartol, K.M.; Zhang, Z.; Li, C. Enhancing employee creativity via individual skill development and team knowledge sharing: Influences of dual-focused transformational leadership. J. Organ. Behav. 2017, 38, 439-458. [CrossRef]

109. Foss, N.J.; Minbaeva, D.B.; Pedersen, T.; Reinholt, M. Encouraging knowledge sharing among employees: How job design matters. Hum. Resour. Manag. 2009, 48, 871-893. [CrossRef]

110. Park, C.H.; Song, J.H.; Lim, D.H.; Kim, J.W. The influences of openness to change, knowledge sharing intention and knowledge creation practice on employees' creativity in theKorean public sector context. Hum. Resour. Dev. Int. 2014, 17, 203-221. [CrossRef]

111. Rahman, Z.; De Clercq, D.; Wright, B.; Bouckenooghe, D. Explaining employee creativity: The roles of knowledge-sharing efforts and organisational context. Acad. Manag. Proc. 2016, 1, 389-394. [CrossRef]

112. Luckin, R.; Issroff, K. Education and AI: Preparing for the Future. 2018. Available online: http://www.oecd.org/education/2030/ (accessed on 18 November 2020).

113. Engel, A.; Coll, C.; Membrive, A.; Oller, J. Information and communication technologies and students' out-of-school learning experiences. Learn. Across Settings Time Digit. Age 2018, 33, 130-149. [CrossRef]

114. Bialik, M.; Fadel, C. Knowledge for the Age of Artifical Intelligence: What Should Students Learn? 2018. Available online: https: // curriculumredesign.org/wpcontent/uploads/CCR_Knowledge_FINAL_January_2018.pdf (accessed on 18 November 2020).

115. Bonekamp, L.; Sure, M. Consequences of industry 4.0 on human labour and work organisation. J. Bus. Media Psychol. 2015, 6, 33-40.

116. Rozkwitalska, M.; Slavik, J. Around learning and Industry 4.0 in management theory. Int. J. Contemp. Manag. 2017, 16, 185-206.

117. Counsell, C. Taking curriculum seriously. Impact J. Chart. Coll. Teach. 2018, 4, 185-206. Available online: https://impact.chartered. college/article/taking-curriculum-seriously/ (accessed on 15 July 2020).

118. Pfeffer, J. Building sustainable organisations. The human factor. Acad. Manag. Perspect. 2010, $24,34-45$.

119. Bratnicka, K. Creativity and effectiveness in organisations. A new approach to an old question. Management 2015, 19, 33-45. [CrossRef]

120. Rhee, Y.W.; Choi, J.N. Knowledge management behaviour and individual creativity: Goal orientation as antecedents and in-group social status as moderating contingency. J. Organ. Behav. 2017, 38, 813-832. [CrossRef]

121. West, M.A. Effective Teamwork. In Practical Lessons from Organisational Research, 3rd ed.; BPS Blackwell: Hoboken, NJ, USA, 2012; Un Secretary-General's Strategy on New Technologies. 2018; Available online: https://www.un.org/en/newtechnologies/ images/pdf/SGs-Strategy-on-New-Technologies.pdf (accessed on 11 April 2020).

122. Eurostat. Available online: https:/ / ec.europa.eu/eurostat/data/database (accessed on 15 June 2020).

123. Leaving No One Behind Report. 2019, UN. Available online: https://reliefweb.int/sites/reliefweb.int/files/resources/367306 eng.pdf (accessed on 2 February 2021).

124. Schwab, K. The Global Competitiveness Report 2019. The World Economic Forum. Available online: http:/ / www3.weforum. org/docs/WEF_TheGlobalCompetitivenessReport2019.pdf (accessed on 9 August 2020).

125. Tao, F.; Wang, Y.; Zuo, Y.; Yang, H.; Zhang, M. Internet of Things in product life-cycle energy management. J. Ind. Inf. Integr. 2016, 1, 26-39. [CrossRef]

126. Iacovidou, E.; Purnell, P.; Lim, M.K. The use of smart technologies in enabling construction components reuse: A viable method or a problem creating solution? J. Environ. Manag. 2018, 216, 214-223. [CrossRef]

127. Habek, P.; Wolniak, R. 2015. Assessing the quality of corporate social responsibility reports: The case of reporting practices in selected European Union member states. Qual. Quant. 2016, 50, 399-420. [CrossRef]

128. Marczewska, M.; Kostrzewski, M. Sustainable Business Models: A Bibliometric Performance Analysis. Energies 2020, 13, 6062. [CrossRef]

129. Zawawi, N.; Wahab, S. Organisational sustainability: A redefinition? Organ. Sustain. 2019, 12. Available online: www. emeraldinsight.com/1755-425X.htm (accessed on 19 December 2020).

130. Liczmańska-Kopcewicz, K.; Pypłacz, P.; Wiśniewska, A. Resonance of Investments in Renewable Energy Sources in Industrial Enterprises in the Food Industry. Energies 2020, 13, 4285. [CrossRef] 